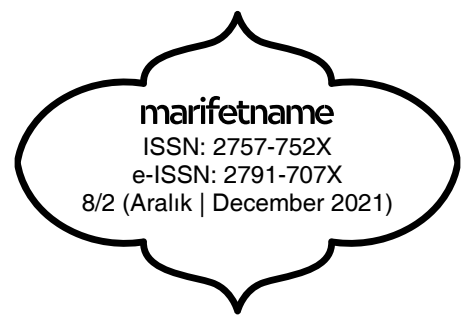

Illahiyat Fakültesi Öğrencilerinin Din Anlayışı

(Van Yüzüncü Yı Üniversitesi llahiyat Fakültesi Örneği)

Religious Understanding of the Faculty of Theology Students (Example of the Faculty of Theology of Van Yuzuncu Yıl University)

\title{
Mesut DÜZCE
}

Dr. Öğr. Üyesi, Van Yüzüncü Y1l Üniversitesi İlahiyat Fakültesi, Van/Türkiye Assist. Prof., Van Yüzüncü Y1l University Faculty of Divinity, Van/Turkey mesutduzce@yyu.edu.tr | orcid.org/ 0000-0001-8599-390X

DOI: $10.47425 /$ marifetname.vi.1016848

Makale Bilgisi | Article Information

Makale Türü | Article Type: Araştırma Makalesi | Research Article

Geliş Tarihi | Received: 31 Ekim / October 2021

Kabul Tarihi | Accepted: 17 Aralık / December 2021

Yayın Tarihi | Published: 30 Aralık / December 2021

\begin{abstract}
Atıf $\mid$ Cite as
Düzce, Mesut. "İlahiyat Fakültesi Öğrencilerinin Din Anlayışı (Van Yüzüncü Yıl Üniversitesi İlahiyat Fakültesi Örneği) [Religious Understanding of the Faculty of Theology Students (Example of the Faculty of Theology of Van Yüzüncü Y1l University)]”. Marifetname. 8/2 (Aralık/2021), s. $607-640$
\end{abstract}

\section{İntihal | Plagiarism}

Bu makale, iThenticate aracilığıyla taranmış ve intihal tespit edilmemiştir. This article, has been scanned by iThenticate and no plagiarism has been detected.

\section{Copyright $($ )}

Published by Siirt University Faculty of Divinity. Siirt/Turkey. web: https://dergipark.org.tr/tr/pub/marifetname mail: sifdergisi@gmail.com 


\section{İlahiyat Fakültesi Öğrencilerinin Din Anlayışı (Van Yüzüncü Yıl Üniversitesi İlahiyat Fakültesi Örneği)}

Öz: Bu çalışma, Van Yüzüncü Y1l Üniversitesi İlahiyat Fakültesi öğrencilerinin dinî eğilimlerini belirlemeye odaklanmaktadır. Çalışmada öğrencilerin dinî eğilimleri tasavvufî, modernist, siyasal ve selefi din anlayışları olmak üzere dört kategori açısından ele alındı. Nicel bir yöntemle yürütülmüş olan bu çalı̧̧mada betimsel tarama modeli ve karşılaştırmalı ilişkisel model kullanılmıştır. Bu çerçevede öğrencilerin ilgi duydukları İslâm anlayışları; cinsiyet, aile gelir düzeyi, mezun olunan lise türü, sınıf, İlahiyat Fakültelerinde eğitimin karma ya da tek cinsiyete dayalı mı olması gerektiği ve öğrencilerin İlahiyat Fakültelerindeki ders gruplarından hangilerine yakınlık duydukları gibi farklı değişkenler üzerinden ölçülmeye çalışıldı. Araştırmanın evreni 2020-2021 eğitim- öğretim yılında İlahiyat Fakültesinde okuyan Hazırlık Sınıfı dışındaki 979 öğrenciyi kapsamaktadır. Örneklem grubu ise farklı sınıflardan ankete cevap veren 441 öğrenciden oluşmaktadır. Araştırmada bilgi toplama kaynağı olarak, kişisel bilgi formu ve 15 maddelik "İslâm Anlayışı Ölçeği” kullanıldı. Araştırma sonucunda Van Yüzüncü Yıl Üniversitesi İlahiyat Fakültesi öğrencilerinin İslâm anlayışlarında tasavvufî İslam anlayış1 yönünde bir eğilimin öne çıktığı görüldü.

Anahtar Kelimeler: Din Sosyolojisi, Tasavvufí İslâm, Modernist İslâm, Siyasal İslâm, Selefi İslâm.

\section{Religious Understanding of the Faculty of Theology Students (Example of the Faculty of Theology of Van Yüzüncü Yıl Univer- sity)}

Abstract: This study focuses on determining the religious tendencies of Van Yüzüncü Y1l University Faculty of Theology students. In the study, the religious tendencies of the students were discussed in terms of four categories: sufistic, modernist, political and predecessor religious understandings. In this study, which was conducted using a quantitative method, the descriptive survey model and the comparative relational model were used. Within this framework, it was tried to measure the students' understanding of Islam through different variables such as gender, family income level, type of high school graduated, class, whether the education should be mixed or single-sex in Theology Faculties and which course groups the students were close to in the faculty. The universe of the research includes 979 students, excluding the Preparatory Class, studying at the Faculty of Theology in the 2020-2021 academic year. The sample group consists of 441 students from different classes who answered the questionnaire. The personal information form and the 15-item "Islamic Understanding Scale" were used as informa- 


\begin{abstract}
tion collection sources in the research. As a result of the research, it was seen that the students of the Faculty of Theology had a tendency towards sufistic understanding of Islam.
\end{abstract}

Keywords: Sociology of Religion, Sufistic Islam, Modernist Islam, Political Islam, Salafi Islam.

\title{
Giriş
}

Türkiyede üniversiteleşme oranı son zamanlarda giderek artmaktadır. Her ile üniversite yapılmasına yönelik ortaya konan hedef 2008 tarihinden itibaren realize edilmeye başlanmı̧̧ ve il düzeyinde üniversitesi olmayan herhangi bir şehir kalmamıştır. Ayrıca İstanbul başta olmak üzere, büyük şehirlerde hem devlet hem vakıf hem de özel sektör marifetiyle pek çok yeni üniversite kurulmuştur. Bunun yanı sıra mevcut üniversitelerin kontenjanları da artırılarak üniversiteli sayısının artması hedeflenmiştir. 2021 YÖK verilerine göre Türkiye'de 131 adet Devlet üniversitesi, 78 adet Vakıf Üniversitesi bulunmaktadır. ${ }^{1}$ Türkiye'de yüksek öğretim sisteminde İlahiyat ve İslâmî İlimler fakülteleri de önemli bir yer tutmaktadır ve son zamanlardaki üniversiteleşme oranının yükselmesine paralel olarak İlahiyat Fakültelerinin de sayıları artmıştır. YÖK verilerine göre hali hazırda 123 adet İlahiyat Fakültesi ve İslâmî ilimler fakültesi bulunmaktadır. Aynı veriler bu fakültelerde her sene istikrarlı bir biçimde yükselen mezun sayılarının 2020-2021 eğitim öğretim döneminde 22.547 kişiye ulaştığını ortaya koymaktadır. ${ }^{2}$

İlahiyat Fakülteleriyle ilgili son dönem gelişmeler sadece bu fakültelerin sayılarının artmasından ibaret değildir. Mevcut İlahiyat Fakültelerinin kontenjanlarının geçmiş ile mukayese kabul etmez bir biçimde arttırılması da bu gelişmelerin içindedir. Mezuniyet sonrası atanma kolaylığı ve eskiden olduğu gibi bir katsayı uygulamasının olmaması nedeniyle İlahiyat Fakülteleri artık sadece İmam-Hatip Liseleri mezunlarının değil sosyal alanlardaki hemen hemen tüm lise mezunlarının ilgisini çekmektedir. Bu durum ise ilahiyat öğrenicilerinin farklı profillere sahip olmasını beraberinde getirmektedir. Dolayısıyla İlahiyat fakültesi öğrencilerinin farklı din anlayış-

\footnotetext{
1 “YÖK Universiteler" (Erişim 22 Ekim 2021).

2 "Yükseköğretim Bilgi Yönetim Sistemi" (Erişim 30 Ekim 2021).
} 
larına sahip olmalarının altında - diğer faktörlerin yanı sıra - bu gerçeğin da altını çizmek gerekmektedir.

Öte yandan, Türkiye'de özellikle din ve modernleşme bağlamında yap1lan tartışmaların sürekli unsurlarından biri olarak karşımıza çıkan İlahiyat Fakülteleri, içinden geçilen zamanın ruhuna uygun olarak kendisine sürekli misyon yüklenen kurumlar olarak ön plana çıkmaktadır. Niteliği ne olursa olsun her dönemin yönetici elitinin ilgisine bütün yüksek öğretim içinde en fazla mazhar olan fakülteler arasında yer alan İlahiyat Fakülteleri, dönemine göre belirli toplumsal tasavvurların "olması gereken" toplum tipinin yakalanabilmesi için operasyonel bir eğitim alanı olagelmiştir. Bu durumun doğal bir uzantısı olarak, ülkede İlahiyat Fakültelerinin sayıları ve öğrenci kontenjanları kimi zaman azaltılırken kimi zaman da arttırılmıştır. Dolayısıyla bu fakülteler - diğer dinî kurumlarla birlikte - bazen dinin devletin kontrolünde olması ve eğitiminin de devletin kurumlarınca üstlenmesi gerektiğine ilişkin anlayışın realize edilmesine aracılık misyonunu yüklenirken bazen de toplumun mevcut dindarlığının yetersiz bulunması nedeniyle onun daha fazla dindarlaşması için bir misyonun yüklenmesiyle karşı karşıya kalmıştır. Anlaşılacağı üzere, burada İlahiyat Fakültelerine ve bu fakültelerin öğrencilerine yüklenen misyon, zihniyetlerin farklılığına bağlı olarak değişmektedir. İlahiyat ve ilahiyatçı algısına ilişkin bu tablo, sadece iktidarların zihniyeti açısından değil, toplumun farklı kesimleri açısından da benzerlik arz etmektedir. Bu açıdan bakıldığında, İlahiyat Fakülteleri ve öğrencilerinin, kendilerine dişarıdan yüklenen anlamlara muhatap oldukları görülmektedir. Ayrıca farklı dinî anlayışların toplumsallaşma amaçlarının temel hedef kitlelerinden biri olmaları nedeniyle de İlahiyat fakülteleri, başka bir bağlamda ilginin merkezi haline gelmektedir. Toplumsal bağlamlarda varlığını sürdürmek isteyen her yapı gibi dinî anlayışlar da hem varlıklarına devam etmek hem de varlık amacına uygun olarak, daha fazla yayılmak için toplumsal taban arayışına girmektedirler. Söz konusu anlayışların doğal hedef kitlelerinden biri olarak görülen İlahiyat fakülteleri öğrencilerinin, Van Yüzüncü Yıl İlahiyat Fakültesi örneğinde, hangi dinî anlayışa eğilim gösterdiklerini tespit etmek bu çalışmanın temel amacıdır. Öğrencilerin farklı eğilimlere sahip olması insanî ve toplumsal gerçeğin doğası gereğidir. Çünkü her ne kadar benzer bir kültür havuzunun içinden 
gelseler de onların her biri farklı aile ve sosyal çevrelerden gelmekte, farklı kaynaklardan beslenmekte dolayısıyla hayatın diğer alanlarında olduğu gibi dinî anlayış konusunda da farklı tercihlerde bulunmaktadırlar.

Dinî anlayışların belirlenmesi ya da dindarlığın ölçülmesi problemi, başta psikoloji ve sosyoloji olmak üzere, sosyal bilimlerin din ile ilgili çalı̧malarında geçmişten beri gündemi meşgul etmektedir. ${ }^{3}$ Esasında, Allport'un da belirttiği üzere, ${ }^{4}$ insanların neye inandıkları, nasıl inandıkları, ne düşündükleri ya da hissettiklerini anlamanın en direkt yolu kendilerine sormaktır. Bu nedenle dindarlığın boyutlarına ya da insanların dinî anlayışlarına odaklanan çalışmalar da en kestirme yol olarak bu yönteme başvurmaktadır. Ancak kişinin kendisini değerlendirmesinin açıkça öznel olduğu ve bu değerlendirmede bazen sadece araştırmacıyı değil kendisini de kandırabileceğini yapılan araştırmalar ortaya koymaktadır. Dolayısıyla katılımcıların verdikleri cevaplar, her ne kadar farklı değişkenlerle karşılaştırılarak belli ölçüde kontrol edilebilirlik imkanını verse de onların kendileriyle ilgili değerlendirmeleri kesinlik arz etme bağlamında değil genel bir fikir verme bağlamında muamele görmelidir.

Bu çalı̧̧mada İlahiyat Fakültesi öğrencilerinin dinî anlayışlarını araştırmak üzere İbrahim Aşlamacı'nın ${ }^{5}$ geliştirmiş olduğu ve "Tasavvufi İslâm Anlayışı", "Modernist İslâm Anlayışı", "Siyasal İslâm Anlayışı" ve "Selefî İslâm Anlayışı” ndan oluşan dört eğilime odaklanan "İslâm Anlayışları Ölçeği” kullanılmıştır. Bu çalışma, insanların ya da bu çalışmadaki katılımc1ların İslâm anlayışlarının sadece bu ölçekte başvurulan kategorilerden bir tanesiyle sinırlı olduğu iddiasında değildir. Böyle bir iddia insan ve toplum gerçeğine aykırı olduğu gibi sosyal bilimin doğasına da uygun düşmemektedir. Ayrıca, bu kategoriler dışında bir İslâm anlayışının olmadığı iddiasını da taşımamaktadır. Çünkü zaten bu konuda farklı İslâm anlayışlarını belir-

3 Joseph H. Fichter, "Sociological Measurement of Religiosity", Review of Religious Research 10/3 (1969), 169-177; Marsha Cutting - Michelle Walsh, "Religiosity Scales: What Are We Measuring in Whom?”, Archive for the Psychology of Religion 30/1 (01 Ocak 2008), 137154.

4 Fichter, “Sociological Measurement of Religiosity”, 169.

5 "İlahiyat Fakültesi Öğrencilerinin İslâm Anlayışları Üzerine Bir İnceleme (İnönü Üniversitesi Örneği)", Islâm ve Yorum II, ed. Fikret Karaman (Malatya: İnönü Üniversitesi Yayınevi, 2018), 457-483. 
lemek amacında olan çok sayıda çalışma da bulunmaktadır.6 Dolayısıyla katılımcıların İslâm anlayışlarının sadece bu ölçekte başvurulan kategorilerle sınırlı olmadığını ve olamayacağını baştan kabul etmekle birlikte, bu dört kategorinin belli oranda katılımcıların, genel din anlayışlarına tekabül edebileceği değerlendirilmektedir.

\section{Kullanılan Ölçekteki İslâm Anlayışları Kategorilerine Genel Bir Bakış \\ 1.1. Tasavvufi İslâm Anlayışı}

Bireyin dünya ile ilgisini kesmek ve nefsini yenerek manevi kirlerden arınmak suretiyle ruhî kuvvetleri harekete geçirmek ve bu şekilde Allah'a yaklaşmak ve kavuşmanın yöntemi olarak nitelendirilen tasavvuf, pratik hayatta ise daha yoğun bir manevi hayat sürmek amaciyla birtakım nitelikler atfedilen kişilerin otoritesine ve karizmasına saygı duyarak, özgür iradeleri ve tercihleriyle bu kişilerin kontrolüne girmek ve dünyayı onların perspektifinden algılayıp yorumlamak olarak anlaşılmaktadır. Tasavvuf yolunu benimseyen birey, bir rehbere/mürşide/şeyhe tam olarak teslim olmak ve onun görüşlerine sıkı sıkıya bağlanmak durumundadır. Şeyhe bağlılık tasavvufun olmazsa olmaz prensiplerindendir. Çünkü Allah’a ulaşmak amacıyla çıkılan manevi bir yolculukta, kişi ancak bu yolculuğu daha önce tecrübe etmiş bir şeyhin/mürşidin denetiminde gerçekleştirirse tehlikelerden emin bir şekilde menziline ulaşabilir. Tasavvufun kaynağı ile ilgili, tasavvufa olan bakış

6 Bunlardan bazıları için bkz. Mutlu Kayhan, "Bir Dindarlık Ölçeği (Sosyoloji'de Yöntem Üzerine Bir Tartışma)", İslâmi Araştırmalar Dergisi 3/4 (1989), 194-199; Veysel Uysal, "İslamî Dindarlık Ölçeği Üzerine Bir Pilot Çalışma”, İslâmi Araştırmalar Dergisi 8/3-4 (1995), 263271; Niyazi Akyüz, "İlahiyat Fakültesi Öğrencilerinin Din Anlayışı Ölçeği Üzerine Bir Pilot Araştırma”, Ankara Üniversitesi İlahiyat Fakültesi Dergisi 43/1 (01 Nisan 2002), 123-134; Niyazi Akyüz, İlahiyat Fakültesi Öğrencilerinin Din Anlayışı (Ankara: Gündüz Eğitim ve Yayıncılık, 2007); Kemaleddin Taş, "Dindarlı̆̆ın Kriterleri Üzerine Tipolojik Bir Araştırma”, Dindarlı̆̆ın Sosyo-Psikolojisi (Adana: Karahan Kitapevi, 2006), 175-206; Mehmet Emin Kalgi vd., "Lisans Öğrencilerinin Değer Yönelimleri: Karşılaştırmalı Bir Analiz-Van Yüzüncü Y11 Üniversitesi Örneği”, BEÜ İlahiyat Fakültesi Dergisi 7/2 (15 Aralık 2020), 559-580; Ali İnan, "Sosyal Sermaye Bağlamında Bölüm Memnuniyeti ve Sosyal Ağ Olarak Okul Ortamına Bakış İlişkisi: İlahiyat Fakülteleri Örneği”, Türkiye Din Eğitimi Araştırmaları Dergisi 8 (29 Aralık 2019), 11-26; Ahmet Aktaş, "İlahiyat Eğitimi Gören Kız Öğrencilerin İslâm Anlayışları (Siirt Üniversitesi Örneği)” Her Dem Kadın. Ed. Gülşen İstek. (İstanbul: Beyan Yayınlar1, 2021), 321-348. 
açısından ilhamını alan birbirine karşıt farklı yaklaşımlar söz konusudur. Bazıları onun İslâm dışı kaynaklardan geldiğini ileri sürerken, bazıları ise onun kaynağının bizzat İslâm olduğunu savunmuşlardır. ${ }^{7}$

Tasavvuf, büyük ölçüde, onu tanımlayan sûfînin içinde bulunduğu hâlin manevî etkisiyle çok farklı tanımlara konu olmuştur. Bu tanımların ortak özelliklerine bakıldığında, "tasavvufun manevi bir yaşam tarzı olarak özelliklerini, Kitap ve Sünnet'le irtibatını, kulun Allah'la ve mâsivâ ile ilişkilerini, kalp temizliği, nefis terbiyesi, güzel ahlâk gibi işlevlerini, sûfînin niteliklerini ve görevlerini belirten” bir kavram olduğu görülmektedir. Bazı sûfiler ise tasavvufun mahiyetini, ona içkin bulunan mertebelere göre açıklama cihetine gitmişlerdir. Buna göre, ilim mertebesinde tasavvuf kalbin bulanıklıktan arındırılması, yaratılanlara karşı güzel muamelede bulunmak ve şer'i konularda Hz. Peygambere uymaktır. Hakikat mertebesinde temel fikir olarak ne sen varsin ne ben, her şey O'dur anlayışı söz konusudur. Dolayısıyla bu mertebede tasavvuf mülkten ve sıfatlardan kurtuluşu ve yaratıcı ile yetinmeyi temsil etmektedir.8

Tasavvufî İslâm anlayışı, insanın beşerî zaaflardan sıyrılarak dünyanın, nefsin ve şeytanın ayartmalarından kurtulmasını ön görmektedir. Bu anlayışa göre, insanın fitratı da bunu gerektirir ve insanın fitratıyla uyumlu bir varoluş ve düşünüş tarzını benimsemesi gerekmektedir. Bu seviyeye ulaşmak ise ancak ciddi bir nefis terbiyesi ve seyr-u süluk ile insani zaaflardan arınmak ve Allah ile kul arasındaki ilişkinin niteliğini anlamakla mümkündür. ${ }^{9}$ Tasavvufî anlayışa göre İslâm, bir şeyhe bağlanarak daha iyi yaşanabilir. Çünkü şeyh seyr-u süluk yolculuğunu tamamlamış ve şeriat, tarikat ve hakikat gibi aşamalardan geçerek tasavvufta yüksek bir mertebeye ulaşmışırı. ${ }^{10}$ Dolayısıyla ona intisap eden kişi şirke değil Allah'a yaklaşmış olur. İslâm düşünce tarihi-

7 Reşat Öngören, “Ehl-i Sünnet'te Tasavvufun Yeri”, Tarihte ve Günümüzde Ehl-i Sünnet, ed. Mahmut Kaya vd. (İstanbul: Ensar Neşriyat, 2006), 162; Mehmet Ali Kirman, Din Sosyolojisi Terimleri Sözlü̆̆̈̈ (İstanbul: Rağbet Yayınları, 2011), “Tasavvuf”, 320.

8 Reşat Öngören, "Tasavvuf”, TDV İslâm Ansiklopedisi (Ankara: TDV Yayınları, 2011), 40/119.

9 Ramazan Akkır, "İlahiyat Fakültesi Öğrencilerinin Din Anlayışları: Tekirdağ Namık Kemal Üniversitesi İlahiyat Fakültesi Örneği”, Siirt Üniversitesi İlahiyat Fakültesi Dergisi 7/2 (30 Aralık 2020), 451.

10 Reşat Öngören, “Şeyh”, TDV İslâm Ansiklopedisi (Ankara: TDV Yayınları, 2010), 39/50. 
nin ilk dönemlerinden itibaren, Hz. Peygamber dönemindeki züht ve takvayı yaşamak ve yaşatmak isteyen tasavvuf ehlinin önce münferit çabalarıla daha sonra da tarikatlar biçiminde kurumsal bir hal alarak günümüze kadar gelmiş devasa bir tasavvuf literatürü bulunmaktadır. Tasavvufí İslâm anlayışı bu literatürü, özü itibarıyla tasavvufun İslâm maneviyatını korumaya ve yaşatmaya yönelik bir çaba olarak değerlendirmektedir. ${ }^{11}$

\subsection{Modernist İslâm Anlayışı}

Uzunca bir geçmişe ve zengin bir literatüre sahip olmasına rağmen modernist İslâm anlayışının ideolojik boyutu olan "İslâm modernizmi” terkibi, özellikle dinî muhafazakarlığın yaygın olduğu İslâm ülkelerinde genellikle yadırganan ve şüpheyle bakılan bir kavramdır. Bunun temel sebebi söz konusu kavramın bu çevrelerde "modernlik", "çağdaşlık", "asrilik", "reform" gibi olumsuz bir imaja sahip olan kavramları çağrıştırmasıdır. Geniş dindar kitleler nezdinde bu ve benzeri kavramlar dinin içeriğinin boşaltılması veya özünün değiştirilmesi olarak algılandığg için antipatiyle karşılanmaktadır. Ayrıca modernizmin Batı ve İslâm toplumlarındaki Batılılaşmış kesimle doğrudan ilişkilendirilmesi de bu bakışı besleyen unsurlar arasında sayılabilir. Ancak İslâm modernizmine - ve dolayısıyla modernist İslâm anlayışına - ilişkin bu değerlendirmelerin isabetli olmadığını belirten Aydın12, İslâm modernizminin ne herhangi bir Müslüman düşünürün ortaya koyduğu veya ortaya koymak istediği bir düşünce ya da anlayışın adının olduğu, ne dinin bir kısmının alınıp geri kalanın güncel şartlara uyarlamak olduğu, ne Batıdan alınan bir sistemin ya da sistemlerin bazı taraflarını alıp bazı taraflarının ise İslâm'ın bazı yönleriyle uzlaştırma girişiminin adı olduğu ne de onun sıradan bir "ihya" hareketi ya da Batı karşısında tepkisel bir anlayış olduğunu ileri sürmektedir.

Doğası gereği, herhangi bir kavrama dair yapılan değerlendirmenin ve tanımlamaların doğru olmadığını ileri sürmek o kavramın doğru tanımının ne olduğunu bilmeyi ima eder. Dolayısıyla buraya kadar "İslâm moderniz-

11 Mehmet Tayfun Amman, “Anlamak ve Arınmak: Sosyoloji ile Tasavvuf Arasında Köprülerin Kurulması", Akademik Platform İslâmi Araştırmalar Dergisi 1/1 (01 Şubat 2017), 21.

12 Mehmet S. Aydın, "Fazlur Rahman ve İslâm Modernizmi", İslâmi Araştırmalar Dergisi 4/4 (1990), 273. 
minin ne olmadığı”na dair değerlendirmelerde bulunan Mehmet S. Aydın "o halde İslâm modernizmi nedir?" sorusuna Fazlur Rahman'ın konuyla ilgili değerlendirmeleri eşliğinde cevap vermektedir. Bu çerçevede, modernist İslâm anlayışının merkezi tezi ana hatlarıyla şu şekilde tasvir edilmektedir: 'Temel kaynakları olan Kur'an ve Sünnet'e dayandırıldiğg, bu kaynaklar ve onların ışı̆̆ında oluşan topyekün taribi miras, ilmî ve rasyonel bir süzgeçten

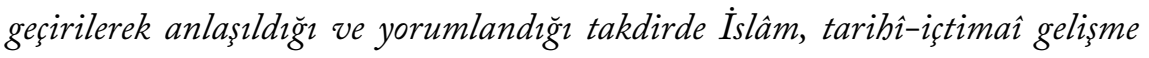
sürecinin ortaya çıkardiğg değişme hadisesinin doğurduğu problemleri çözmeye, o sürecin altında ezilmeye değil ona yön vermeye kâdir bir inanç sistemidir." Aydın'a göre13 Modernist İslâm anlayışı bu tezle iki yönlü bir ilişki içinde olmaktadır: İlk olarak, onun ilim ve mantık açısından geçerli olduğunu kanitlamak ve ikinci olarak da, ulaşılan çözümleri Müslümanların gündelik hayatlarının ve pratiklerinin bir parçası haline getirmek. İlk boyutla ilgili, yani İslâm'ın ilmen ve mantıken geçerli olduğunu kanıtlamak konusunda ciddi bir çabanın ortaya konduğu ve gözle görülür bir ilerlemenin sağlandığ1 söylenebilse de meselenin ikinci boyutu olan pratik boyutu konusunda kayda değer bir mesafenin alındığını söyleme imkânı oldukça sınırlıdır.

Özetlemek gerekirse, modernist İslâm anlayışı, modern problemleri İslâm'ın ana kaynaklarına müracaat ederek çözmeye çalışan bir anlayış olarak değerlendirmek mümkündür. Bu anlayış, sanılanın aksine, geleneği ihmal etmekten ziyade geleneğin normatif karakterde görülmesine veya kutsallaştırılmasına karşı çıkmaktadır. "Rasyonelliği beşerî tecrübenin bütünlüğünde görmesi”14 en önemli özellikleri arasında yer almaktadır. Ayrıca, modernist İslâm anlayışı, Asr-1 Saadetteki inanç ve pratikleri günümüzde yeniden canlandırmak isteyen, "Kur'an ve sünnete, selefîn akîde ve uygulamalarına dönme" noktasında selefilik anlayışıyla uzlaşmaktadırlar. Ancak selefilik “olduğu gibi” geçmişe dönme, başka bir ifade ile "saf İslâm’a dönüş" tezini savunurken, modernist İslâm geçmişi yeniden yorumlamayı ve içinde bulunulan sosyal-tarihsel gerçekliği göz önünde bulundurarak rasyonel bir biçimde anlamayı ve anlaşılır kılmayı tercih etmektedir. ${ }^{15}$

13 “Fazlur Rahman ve İslâm Modernizmi”, 274.

14 Mehmet S. Aydın, “Rasyonel Düşünce ve İslâm Modernizmi”, I. İslâm Düşüncesi Sempozyumu, ed. Mehmet Bekaroğlu (İstanbul: Beyan Yayınları, 1995), 149.

15 Aydın, "Fazlur Rahman ve İslâm Modernizmi”, 274-275; Mustafa Sönmez, "İslâm Moderniz- 


\subsection{Siyasal İslâm Anlayışı}

Siyasal İslâm, İslâm'ı siyasal kimlik ve eylemin kaynağı olarak gören bir anlayış olarak ifade edilebilir. Siyasal İslâm, devleti ve toplumu İslâmî kılmak üzere dönüştürmek için çaba sarf eden çok sayıda kişi ve gruba gönderme yapan bir ifadedir. O, bir "İslâmî devlet" ya da "İslâmî düzen" tesis etmeye dönük çeşitli girişimlerin yanı sıra bir inanç seti, davranı̧̧ kuralları ya da siyasetle ilgili bir dizi metafor veya imaj olarak tasarlanan İslâm’a gönderme yapmaktadır. ${ }^{16}$

Müslümanların geçmiş dönemlerdeki başarıları ve kurdukları büyük devletlerin gücünü kaybetmeleriyle başlayan sömürge dönemi ve Batıl1ların artık kalıcı hale gelmiş hakimiyeti, öteden beri İslâm dünyasındaki entelektüellerin gündemini meşgul etmektedir. İslâm dünyasının içinde bulunduğu durum üzerinde kafa yormak ve İslâm toplumunu yeniden canlandırmak ve eski ihtişamına kavuşturmak için pek çok birey ve grup çaba sarf etmiştir. ${ }^{17}$

İslâm dünyasının içinde bulunduğu mevcut durumun nedenleri konusunda bir uzlaşma bulunmamakla birlikte, onun asırlardır düşüş içinde olduğuna dair bir ihtilaf bulunmamaktadır. Bazı entelektüeller İslâm dünyasının büyüsünü kaybetmesinin sebebi olarak İslâm’ın getirmiş olduğu ilahi yasa olan şeriat yolunun terkedilmesi olduğunu ileri sürmektedirler. Onlara göre eğer Müslümanlar gerçek şeriatı uygularsa tarihte atalarının bulunduğu konuma tekrar gelirler. Onlar bir toplumsal düzen tesis etmenin en iyi yolunun ilahi şeriat olduğunu düşünürler ve Müslümanlar bu yolu terk ettikleri için düşüşe geçmişlerdir. Arap dünyasındaki Müslüman Kardeşler ile Güney Asyadaki Cemaati İslâmî hareketleri bu temel önermeye dayanmaktadır. Bunlara göre, şeriatın sistemli bir şekilde uygulanması halinde Müslümanlar bir kez daha küresel aktör haline geleceklerdir.18

Bir ideoloji olarak Siyasal İslâmcılık, İslâm’ı bireysel yaşamla sınırlı ka-

minin Doğuşu ve İki Önemli Temsilcisi (Afgânî ve Abduh'un Modernist Yönlerine Kısa Bir Bakış)", Atatürk Üniversitesi İlahiyat Fakültesi Dergisi 18 (30 Aralık 2002), 151.

16 Gudrun Krämer, "Political Islam", Encyclopedia of Islam and the Muslim World, ed. Richard C. Martin (New York: Macmillan, 2004), 2/536.

17 Konuyla ilgili kapsamlı bir bibliyografya için bkz. Yvonne Y. Haddad vd., The Contemporary Islamic Revival: A Critical Survey and Bibliograpy (Westport: Greenwood, 1991).

18 Muqtedar Khan, “What Is Political Islam?”, E-International Relations (2014). 
lan bir din olmadığını ileri sürerek, onu aşan ve siyasal, kültürel, ekonomik, hukuki, eğitim vb. toplumsal bütün alanlara ilişkin düzenleyici hükümler ihtiva eden bütüncül ve kapsamlı bir sistem olarak görmektedir. Bu doğrultuda bir inanç geliştirmek ve sistemin ete kemiğe bürünmesi için çalışmayı ise farz olarak değerlendirmektedir. ${ }^{19}$ Dolayısıyla İslâmî bir toplumun yaratılması siyasal İslâmcılık açısından temel hedef olarak öne çıkmaktadır. Bu temel hedefin gerçekleştirilmesi ise ancak siyaset kurumuyla mümkündür. İslâmcılar hedeflenen İslâmî toplumun yaratılması için siyasal iktidarın bir zorunluluk olduğu noktasında neredeyse görüş birliği içindedirler. Çünkü, onlara göre, sadece vaaz vererek İslâm'ın tesis etmek istediği toplumsal düzenin yakalanabilmesi mümkün değildir. Bu düzen ancak siyasal iktidara sahip olunduğunda kurulabilir. ${ }^{20} \mathrm{Bu}$ çerçevede, örneğin, Hurşid Ahmed, Mevdudi'nin Islamic Law and Constitution isimli eserine yazdığı girişte “İslam'ın getirmek istediği reformlar sadece ritüellerle yerine getirilemez. Bunları gerçekleştirmek için siyasal iktidar da gerekmektedir"21 diye yazmaktadır. İslamcılığın entelektüel kökenlerinin dayandığı düşünürlerden biri olan Mevdudi de benzer bir görüşü serdetmektedir: "Bir Müslüman, İslami olmayan bir hükümet sisteminin otoritesi altında hayatını İslam' 1 n öğretilerine göre düzenleyemez."22 Benzer bir vurguya Seyyid Kutup’ta da görülmektedir.23 Bununla birlikte, başka herhangi bir ideoloji ya da akım gibi İslamcılığın da yek pare olmadığını, içinde farklılıklar barındırdığını gözden kaçırmamak gerekmektedir.

\subsection{Selefî İslâm Anlayı̧̧ı}

Selef sözcüğü sözlükte “önceki nesil”, “önce gelenler”, “geçmişte kalmak” gibi anlamlara gelmektedir. İslâm düşünce tarihindeki bir terim olarak ise selef, Müslümanların ilk üç nesli anlamında kullanılmaktadır. Bu çerçevede, Selefîlik, İslâm'ı anlama, yorumlama ve yaşama konusunda İslâm tarihin-

19 Sönmez Kutlu, Çă̆gaş İslâmî Akımlar (Ankara: Fecr Yayınları, 2008), 40-41.

20 Olivier Roy, Siyasal İslâm'ın İflası, çev. Cüneyt Akalın (İstanbul: Metis Yayınları, 1993), 90.

21 Khurshid Ahmad, "Introduction", The Islamic Law and Constitution (Lahore: Islamic Publication, 1980), 5 .

22 S. Abui A'la Maududi, Jihad in Islam (Lahore: Islamic Publication, 1939), 18.

23 Sayyid Qutb, "War, Peace and Islamic Jihad", Modernsit and Fundamentalist Debates in Islam, ed. Mansoor Moaddel - Kamran Talattof (New York: Palgrave Macmillan, 2002), 241. 
deki ilk üç nesli model olarak kabul eden ${ }^{24}$ onların fikir ve uygulamalarını takip edenlerin oluşturduğu anlayışa verilen isimdir. Başka bir ifadeyle bir zihniyet ya da anlayış olarak selefilik, Müslümanların ilk nesillerinin ruhunu canlandırmak amacında olan bir harekete gönderme yapmaktadır.

İlk nesillerin ruhunu yeniden canlandırma amacı selefilikte iki yöntemle kendisini göstermektedir. İlk olarak, her şey Kur’an, sünnet ve şeriata irca edilmekte ve başvurulan kaynaklar mutlak bir lafzîlikle ele alınmaktadır. Bu anlayışın bir uzantısı olarak insanların bütün eylemleri dinî bir çerçevede değerlendirilmektedir. İkinci olarak, saf İslâm geleneğine sonradan ilave edilen her şey sapıklık, hurafe ya da bid'at olarak görülmektedir. 25 Dolayısıyla sonradan eklemlenen şeylerin niteliğine bakılmaksızın sökülüp atılması ve reddedilmesi gerekmektedir. Selefîlik, modern çağda canlı bir Müslüman toplumunu yeniden oluşturma arayışında olup İslâm'ın modern dönemlerde Müslümanlara temel ilham ve rehberlik kaynağı olarak hizmet edebilmesi için öncelikle onun asırlardır biriken pek çok yanlış anlama ve çarpıtmadan kurtarılması gerektiğini savunmaktadır. ${ }^{26}$

İslâm'da bir reformdan söz edilecekse Selefîlik için reform, İslâm'1 bu yanlış anlamalardan ve çarpıtmalardan arındırmak anlamına gelmektedir. Çünkü Selefîliğe göre, ancak bu şekilde erken dönem Müslüman toplumunun yaratıcı ruhu yeniden canlandırılabilir. Müslüman dünyanın gücünün ve etkisinin Batı'ya göre düşüşte olduğunu gören modern Selefîliğin temel kaygısı ve amacı İslâm'1 çağdaş dünyada dinamik bir güç haline getirmektir. ${ }^{27} \mathrm{Bu}$ amaca ulaşmanın yolu taklitçiliği reddederek Kur'an ve sünnete dönüş yapmaktır. İslâm dünyası ancak bu şekilde asırlardır devam eden zayıflık ve çöküşten kurtulabilir ve yeniden doğuşunu gerçekleştirebilir. ${ }^{28}$

Dinin 'gerçek anlamda' anlaşılması ve yaşanması konusunda İslâm'ın ilk üç neslinin - olduğu gibi - model olarak alınması, ayet ve hadislerin anla-

\footnotetext{
24 Ferhat Koca, "İslam Düşünce Tarihinde Selefilik: Tarihsel Serüveni ve Genel Karakteristiği”, İlahiyat Akademi 1-2 (19 Ekim 2015), 15.

25 Mehmet Zeki İşcan, “Tarih Boyunca Selefî Söylem”, İlahiyat Akademi 1-2 (19 Ekim 2015), 2.

26 Krämer, "Political Islam", 2/537.

27 John O. Voll, "Salafiyya”, Encyclopedia of Islam and the Muslim World, ed. Richard C. Martin (New York: Macmillan, 2004), 2/609.

28 Krämer, "Political Islam”, 2/537.
} 
ş1lmasında aklın belirleyiciliğine karşı çıkan, İslâm'ı saflığından uzaklaştırdığına inanılan zaid bütün unsurlara karşı cephe alan selefîlik homojen bir niteliğe sahip değildir. İlk dönem selefîliğiyle modern dönem selefîliği arasında olduğu gibi çeşitli selefî gruplar arasında da birtakım farklılıklar bulunmaktadır. Bu farklılıklara girmek bu çalışmanın amacı ve sınırları dahilinde değildir. Bununla birlikte, Selefî İslâm anlayışın öne çıkan temel özelliklerini şu şekilde sıralamak mümkündür: Selefîn görüş ve uygulamalarını dinî bir kaynak ve otorite olarak kabul etmek; Taklit, hurafe ve bid'atların terk edilerek Kur'an ve sünnete yani saf İslâm'a dönmek; Allah'ın sıfatlar1nı, te'vil etmeden olduğu gibi kabul etmek; Müteşabih ayetleri yorumlamamak, o ayetlerden kastedilen manayı Allah'a havale etmek; Müteşabih ayet ve hadisleri aklın ışı̆̆ında yorumlayanları bid'atçı ve sapık olmakla itham etmek; İman-amel birlikteliğini savunmak ve amelsiz imanı küfür saymak; Akıl-nakil ilişkisinde naklin üstün olduğunu savunmak; Kur'an ve sünneti eşit kategoride saymak. ${ }^{29}$

\section{Araştırmanın Amacı ve Yöntemi}

$\mathrm{Bu}$ çalışmanın temel amacı Van Yüzüncü Y1l Üniversitesi İlahiyat Fakültesi öğrencilerinin, kullanılan ölçeğin geliştirmiş olduğu dört farklı İslâm anlayışı çerçevesinde, nasıl bir İslâm anlayışına sahip olduklarını saptamaktır. Bu bağlamda öğrencilerin sahip oldukları İslâm anlayışı cinsiyet, sınıf, ekonomik durum, mezun olunan lise, İlahiyat fakültesinde yakınlık duydukları ders grubu vb. gibi değişkenler açısından analiz edilmesi de amaçlanmaktadır. Bu çerçevede cevabı aranan alt problemleri şu şekilde sıralamak mümkündür:

a. Van Yüzüncü Y1l Üniversitesi İlahiyat Fakültesi öğrencileri nasıl bir İslâm anlayışına sahiptir?

b. Van Yüzüncü Y11 Üniversitesi İlahiyat Fakültesi öğrencileri, kullanılan ölçekte yer alan İslâm anlayışlarından en çok hangisine eğilimlidir?

29 Koca, "İslam Düşünce Tarihinde Selefilik”; Aşlamacı, "İlahiyat Fakültesi Öğrencilerinin İslâm Anlayışları Üzerine Bir İnceleme (İnönü Üniversitesi Örneği)"; Akkır, "İlahiyat Fakültesi Öğrencilerinin Din Anlayışları". 
c. Öğrencilerin sahip oldukları İslâm anlayışılla yukarıda sıralanan değişkenler arasında anlamlı bir farklılık var mıdır?

Bu çalı̧̧mada, İlahiyat Fakültesi öğrencilerinin İslâm anlayışı tasviri olarak tespit edilmeye çalışıldığı için betimsel tarama modeli, öğrencilerin sahip olduğu anlayışın bazı değişkenler açısından karşılaştırılması hedeflendiği için de karşılaştırmal ilişkisel model kullanılmıştır. Veriler ise anket tekniğinden faydalanılarak elde edilmiştir. Araştırma evrenini 2020-2021 öğretim yılında Van Yüzüncü Y11 Üniversitesi İlahiyat Fakültesinde okuyan, hazırlık sınıfı dışındaki, öğrenciler oluşturmaktadır. Araştırma evrenine dahil olan öğrenci sayısı 979'dur. Çalışmanın örneklemi ise Birinci sınıftan 103, İkinci Sınıftan 110, Üçüncü sınıftan 90 ve Dördüncü sınıftan 138 olmak toplam 441 öğrenciden oluşmaktadır. Çalışmamız COVİD-19 salgınının dayattığı koşullar dolayısıyla uzaktan eğitimin yapıldığ 1 bir ortamda gerçekleştirilmiştir. Bu çerçevede, salgınının dayattığı sınırlamalar göz önünde bulundurularak ve zamandan, mali kaynaklardan ve enerjiden tasarruf sağlamak amacıyla veri toplama işlemi Google formları üzerinden tasarlanan bir anket arac1lığıyla gerçekleştirilmiştir. 30

Örneklemin seçildiği strateji nedeniyle sonuçlar kolayca genelleştirilemese de bu prosedür hızlı ve düşük ekonomik maliyet nedeniyle bilgi toplamaya hizmet etmiştir. İslâm anlayışı ile ilgili kategorilerin temsili bir şekilde önceden belirlenmesi öğrencileri dinî anlayışla ilgili oluşturdukları genel imajın ortaya çıkmasına olanak tanımaktadır. Soruların, söz konusu konunun kapsamını tam olarak kapsamamasına rağmen, soruları iki bölüme ayırmak ve önceden belirlenmiş seçeneklere sahip olmak, bu olgunun çeşitli boyutlarını istatistiksel olarak ölçmemizi sağlamaktadır. Verilerin analizi ve yorumlanması, farklı İslâm anlayışlarıyla ilgili olarak öğrencilerin eğilimlerini tespit etmeyi amaçlamaktadır.

Örneklemin yapısal kategorilere dağılımı şu şekilde gerçekleşmiştir:

30 Online anketlerin avantajı düşük maliyetli ve kısa sürede yapılabilmeleridir. Bununla birlikte bazı araştırmacılar örnekleme, yanıt oranı ve yanıt vermeyen niteliklerle ilgili olarak bazı dezavantajlardan söz etmektedirler Bkz. Durga M. S. Prasad - K.A. Narayan, "Strengths and Weaknesses of Online Surveys", Journal of Humanities and Social Sciences 5/5 (2019), $31-38$. 
cinsiyet: kadınlar (315), erkekler (126); yaş: 18-22 yaş (220), 23-28 yaş (206), 29 yaş üstü (15); gelir düzeyi: yüksek (10), orta (165), düşük (266); mezun olunan lise: İHL/AİHL (261), Diğer liseler (180); hangi sınıfta olduğu: Birinci Sınıf (103), İkinci Sınıf (110), Üçüncü Sınıf (90), Dördüncü Sınıf (138); İlahiyat fakültesinde eğitimin niteliği: karma (229), ayrı (176), fikrim yok (36); Fakültedeki ders gruplarına yakınlık: Temel İslâm Bilimleri dersleri (239), Felsefe ve Din Bilimleri dersleri (167), İslâm Tarihi ve Sanatları dersleri (35).

Bu çalı̧̧mada, demografik bilgilere yer veren kişisel bilgi formu ile İnönü Üniversitesi İlahiyat Fakültesi öğretim üyelerinden İbrahim Aşlamacı'nın geliştirmiş olduğu 15 maddelik İslâm Anlayışı Ölçeği veri toplama aracı olarak kullanılmıştır. Söz konusu ölçek 15 madde ve 4 alt boyuttan oluşmaktadır. Ölçeğin boyutları tasavoufî̀ İlâm anlayışı, modernist İslâm anlayışı, siyasal İslâm anlayışı ve selefi İslâm anlayışı şeklinde isimlendirilmiştir. Ölçeğin yapı geçerliliğini tespit edebilmek için yapılan faktör analizi ve analiz öncesinde verilerin faktör analizine uygunluğunu saptamak için yapilan Kaiser Mayer Olkin (KMO) ve Barlett test sonucunda KMO değeri .764 bulunurken, Barlett testinin değeri ise .000 anlamlı $(\mathrm{p}<.01)$ olarak bulunmuştur. ${ }^{31}$ Bulunan değerler açısından ölçeğin faktör analizi için uygun olduğu sonucu ortaya çıkmıştır. ${ }^{32}$ Tabloların yorumlanmasında bir karışıklık olmaması ve kolaylık sağlaması açısından .30'un altında kalan yüklerin tablolarda yer verilmemesi sağlanmıştır. Boyutlarla ilgili toplam varyans oran1 \%50,67 olarak gerçekleşmiştir.

Bu çalışmadaki veriler 2020-2021 öğretim yılı bahar döneminde elde edilmiştir. Anket İlahiyat Fakültesi öğrencilerine, pandemi koşullarının gerektirdiği zorunluluktan dolayı online olarak uygulanmıştır. Anket formu uygulanmadan önce anket ve amacıyla ilgili bilgilendirme yapılmı̧ ve raporlamada kişisel bilgilerin verilmeyeceği, sonuçların ise toplu olarak değerlendirileceği ifade edilmiştir. Hazırlanan anket soruları, yayın etiği açısından ve insan katılımına dayalı olması bakımından Van Yüzüncü Yı1 Üniversitesi

\footnotetext{
31 Aşlamacı, "İlahiyat Fakültesi Öğrencilerinin İslâm Anlayışları Üzerine Bir İnceleme (İnönü Üniversitesi Örneği)”, 469.

32 Ezel Tavşancıl, Tutumların Ölçülmesi ve SPSS ile Veri Analizi (Ankara: Nobel Yayıncılık, 2002), 67.
} 
Sosyal ve Beşerî Bilimleri Yayın Etik Kurulu'nun 07/09/2021 tarih ve 2021/12 sayılı oturumunda araştırma etik kurulu tarafindan uygun bulunmuştur.

Araştırmada elde edilen verilerin çözümlenmesi SPSS-26 paket programinda gerçekleştirilmiştir. Verilerin analizinde frekans, yüzde, aritmetik ortalama ve standart sapma gibi betimsel istatistikler yapılmıştır. İlahiyat Fakültesi öğrencilerinin sahip oldukları İslâm anlayışlarının çeşitli değişkenlere göre anlamlı şekilde farklılık gösterip göstermediğini tespit amacıyla, normallik testi sonucu uygun olduğundan, ikili gruplar için t-testi, ikiden fazla gruplar için ise tek yönlü varyans analizi (ANOVA) uygulanmıştır. Grupların İslâm anlayışı ölçeğinden aldıkları puanların farklılaştığı sonuçlarda farklılaşan grupları bulmak amaciyla, grupların ortalama puanları arasında Post-Hoc çoklu karşılaştırma testlerinden LSD analizi kullanılmıştır. Ölçekten elde edilen puanların hesaplanması ve değerlendirilmesinde dikkate alınan puan sınırları aşağıdaki tabloda gösterildiği şekildedir:

Tablo 1: Beşli Dereceleme Ölçeği Puan Sıralamaları

\begin{tabular}{|l|l|l|l|l|}
\hline Derece & Puan & Sınırlar & Düzeyler & Sınırlar \\
\hline Kesinlikle katılmıorum & 1 & $1.00-1.79$ & \multirow{2}{*}{ Düşük düzey } & \multirow{2}{*}{$1.00-2.59$} \\
\cline { 1 - 3 } Katılmıyorum & 2 & $1.80-2.59$ & & \\
\hline Kararsızım & 3 & $2.60-3.39$ & Orta düzey & $2.60-3.39$ \\
\hline Katılıyorum & 4 & $3.40-4.19$ & \multirow{2}{*}{ Yüksek düzey } & $3.40-5.00$ \\
\cline { 1 - 3 } Kesinlikle katıllyorum & 5 & -5.00 & & \\
\hline
\end{tabular}

\section{Bulgu ve Yorumlar}

\section{1. İslâm Anlayışı Ölçeği Alt Boyutlanına İlişkin Betimsel Bulgular}

Çalışmaya katılım gösteren Van Yüzüncü Y1l Üniversitesi İlahiyat Fakültesi öğrencilerinin sahip oldukları İslâm anlayışlarını saptamak için uygulanan ölçeğin alt boyutlarına ilişkin betimsel bulgular tablo 2'de yer almaktadır. 
Tablo 2: Ölçeğin Alt Boyutlarına İlişkin Betimsel Bulgular

\begin{tabular}{|l|l|l|l|l|}
\hline Boyutlar & N & X & Ss. & Düzey \\
\hline Tasavvufi İslâm Anlayışı & 441 & 3.90 & .90 & Yüksek düzey \\
\hline Modernist İslâm Anlayı̧̧1 & 441 & 2.77 & .77 & Orta düzey \\
\hline Siyasal İslâm Anlayışı & 441 & 1.90 & .79 & Düşük düzey \\
\hline Selefí İslâm Anlayışı & 441 & 3.17 & .87 & Orta düzey \\
\hline
\end{tabular}

Tablo 2'de görüldüğü üzere, çalı̧̧maya katılım gösteren öğrencilerin sahip oldukları İslâm anlayışları en yüksekten başlamak koşuluyla ortalama puanları sırasıyla tasavvufi İslâm anlayışı $(X=3.90)$, selefî İslâm anlayışı $(X=3.17)$, modernist İslâm anlayışı $(X=2.77)$ ve siyasal İslâm anlayı̧̧ı $(X=1.90)$ olarak gerçekleşmiştir. Bu verilere göre, öğrencilerin tasavvufî İslâm anlayışlarına katılım düzeyleri yüksek, modernist ve selefî İslâm anlayışlarına katılım düzeyleri orta ve siyasal İslâm anlayışına katılım düzeyleri ise düşük derecededir.

\subsection{Bă̆ımsız Değģşkenlere İlişkin Bulgular}

Tablo 3: Cinsiyet Değişkenine Göre İslâm Anlayışı Boyutlarına Ait t Testi Analizi

\begin{tabular}{|c|c|c|c|c|c|c|}
\hline & Cinsiyet & $\mathbf{N}$ & $\mathrm{X}$ & Ss. & $\mathbf{t}$ & $\mathbf{P}$ \\
\hline \multirow{2}{*}{ Tasavvufî İslâm Anlayışı } & $\mathrm{K}_{1 z}$ & 315 & 4.00 & .80 & \multirow{2}{*}{3.017} & \multirow{2}{*}{.003} \\
\hline & Erkek & 126 & 3.68 & 1.08 & & \\
\hline \multirow{2}{*}{ Modernist İslâm Anlayışı } & $\mathrm{K}_{12}$ & 315 & 2.71 & .70 & \multirow{2}{*}{-2.332} & \multirow{2}{*}{.021} \\
\hline & Erkek & 126 & 2.92 & .93 & & \\
\hline \multirow{2}{*}{ Siyasal İslâm Anlayışı } & $\mathrm{K}_{1 z}$ & 315 & 1.92 & .74 & \multirow{2}{*}{.602} & \multirow{2}{*}{.548} \\
\hline & Erkek & 126 & 1.86 & .92 & & \\
\hline \multirow{2}{*}{ Selefi İslâm Anlayışı } & $\mathrm{K}_{1 z}$ & 315 & 3.08 & .85 & \multirow{2}{*}{-3.206} & \multirow{2}{*}{.001} \\
\hline & Erkek & 126 & 3.38 & .88 & & \\
\hline
\end{tabular}

Tablo 3 incelendiğinde, İslâm Anlayışı ölçeği alt kategorilerinden tasavvufî, modernist ve selefî İslâm anlayışlarının puan ortalamaları arasında cinsiyet değişkenine göre istatistiksel olarak anlamlı bir farklılığın 
oluştuğu, siyasal İslâm anlayışında ise oluşmadığı $(\mathrm{t}=.602$, p=.548) görülmektedir. Tasavvufî İslâm anlayı̧ıı kategorisinde kız öğrencilerin aritmetik ortalaması $X=4.00$ ile erkek öğrencilerin aritmetik ortalamasının $X=3,68$ arasındaki farkın anlamlılığını ortaya koymak amacıyla hesaplanan t değerinin ( $\mathrm{t}=3.017, \mathrm{p}<.01)$.01 düzeyinde anlamlı bir farkı ifade ettiği tespit edilmiştir. Bu bulgu iki grup arasında .01 düzeyinde anlamlı bir fark olduğunu göstermektedir. Analiz sonucu, kız öğrencilerin erkek öğrencilere göre daha yüksek düzeyde Tasavvufî İslâm anlayışına sahip olduklarını ortaya koymaktadır. Aşlamacı'nın araştırmasında tam tersi bir sonuç bulunmuş ve erkek öğrencilerin kız öğrencilerine göre daha yüksek düzeyde Tasavvufî İslâm anlayışına sahip oldukları bulunuştur. 33

Modernist İslâm anlayışı kategorisinde kız öğrencilerin aritmetik ortalaması $\mathrm{X}=2.71$ ile erkek öğrencilerin aritmetik ortalamasının $\mathrm{X}=2,92$ arasindaki farkın anlamlılığını ortaya koymak amacıyla hesaplanan $t$ değerinin $(\mathrm{t}=-2.332, \mathrm{p}<.05) .05$ düzeyinde anlamlı bir farkı ifade ettiği tespit edilmiştir. Bu bulgu iki grup arasında .05 düzeyinde anlamlı bir fark olduğunu göstermektedir. Analiz sonucu erkek öğrencilerin kız öğrencilere göre daha yüksek düzeyde modernist İslâm anlayışına sahip olduklarını ortaya koymaktadır. Bu kategoride de Aşlamacı'nın araştırması çalışmamızın ulaşt1ğ1 sonuçların tersi sonuçlar ortaya koymuş ve kız öğrencilerin Modernist İslâm anlayışına katılımlarını erkeklere oranla daha yüksek bulmuştur. ${ }^{34}$ Buna karşılık, çalışmamızın bu kategorideki sonuçları Akyüz'ün çalışmasiyla paralellik arz etmektedir. 35

Selefî İslâm anlayışı kategorisinde ise kız öğrencilerin aritmetik ortalaması $X=3.08$ ile erkek öğrencilerin aritmetik ortalamasının $X=3,38$ arasındaki farkın anlamlılığını ortaya koymak amacıyla hesaplanan $t$ değerinin $(\mathrm{t}=-3.206, \mathrm{p}<.01) .01$ düzeyinde anlamlı bir farkı ifade ettiği tespit edilmiştir. Bu bulgu iki grup arasında .01 düzeyinde anlamlı bir fark olduğunu göstermektedir. Analiz sonucu erkek öğrencilerin kız öğrencilere göre

\footnotetext{
33 Aşlamac1, "İlahiyat Fakültesi Öğrencilerinin İslâm Anlayışları Üzerine Bir İnceleme (İnönü Üniversitesi Örneği)", 474.

34 Aşlamacı, "İlahiyat Fakültesi Öğrencilerinin İslâm Anlayışları Üzerine Bir İnceleme (İnönü Üniversitesi Örneği)”, 474.

35 Akyüz, Ilahiyat Fakültesi Öğrencilerinin Din Anlayışı, 91.
} 
daha yüksek düzeyde Tasavvufî İslâm anlayışına sahip olduklarını ortaya koymaktadır. Aşlamacı'nın araştırmasında selefî İslâm anlayışında cinsiyete göre anlamlı bir farklılık bulunmamıştır. ${ }^{36}$

Tablo 4: Aile Gelir Değişkenine Göre İslâm Anlayışı Boyutlarına Ait ANOVA Testi Analizi

\begin{tabular}{|c|c|c|c|c|c|c|c|}
\hline Boyutlar & Aile gelir & $\mathbf{N}$ & $\mathrm{X}$ & Ss & $\mathbf{F}$ & $\mathbf{p}$ & LSD \\
\hline \multirow{3}{*}{$\begin{array}{c}\text { Tasavvufî } \\
\text { İslâm Anlayış1 }\end{array}$} & İyi & 10 & 3.80 & 1.20 & \multirow{3}{*}{2.24} & \multirow{3}{*}{.108} & \multirow{3}{*}{$2-3$} \\
\hline & Orta & 165 & 3.80 & .93 & & & \\
\hline & Düşük & 266 & 3.98 & .87 & & & \\
\hline \multirow{3}{*}{$\begin{array}{c}\text { Modernist } \\
\text { İslâm Anlayışı }\end{array}$} & İyi & 10 & 2.94 & 1.1 & \multirow{3}{*}{2.17} & \multirow{3}{*}{.115} & \multirow{3}{*}{$2-3$} \\
\hline & Orta & 165 & 2.86 & .79 & & & \\
\hline & Düşük & 266 & 2.71 & .75 & & & \\
\hline \multirow{3}{*}{$\begin{array}{c}\text { Siyasal } \\
\text { İslâm Anlayış1 }\end{array}$} & İyi & 10 & 2.27 & .97 & \multirow{3}{*}{3.67} & \multirow{3}{*}{.026} & \multirow{3}{*}{$2-3$} \\
\hline & Orta & 165 & 2.79 & .77 & & & \\
\hline & Düşük & 266 & 1.97 & .79 & & & \\
\hline \multirow{3}{*}{$\begin{array}{c}\text { Selefi } \\
\text { İslâm Anlayış1 }\end{array}$} & İyi & 10 & 2.90 & .92 & \multirow{3}{*}{.540} & \multirow{3}{*}{.583} & \\
\hline & Orta & 165 & 3.19 & .90 & & & \\
\hline & Düşük & 266 & 3.17 & .85 & & & \\
\hline
\end{tabular}

Tablo 4'den anlaşıldığı üzere gelir durumunu iyi olarak ifade edenlerin sayısı (10) toplam sayı içerisinde (441) oldukça düşük bir orana tekabül etmektedir. Bu durumun aile gelir kategorileri arasında, eğer varsa, anlamlı bir farkın tabloya yansımasını engellediği düşünülmektedir. Nitekim, tasavvufî İslâm anlayışında gelir düzeyinin "iyi” olduğunu belirtenler ile "orta" olduğunu belirtenlerin aynı düzeyde olduğu sonucu (her ikisinde de $\mathrm{X}=3.80$ ) çıkmasına rağmen yapilan test sonucu düşük düzeydekilerin sadece orta düzeydekilerle anlamlı bir şekilde farklılaştıkları görülmüştür. Aynı durum diğer alt boyutlar için de geçerlidir.

36 Aşlamacı, "İlahiyat Fakültesi Öğrencilerinin İslâm Anlayışları Üzerine Bir İnceleme (İnönü Üniversitesi Örneği)", 474. 
Tablo 4'de görüldüğü üzere, öğrencilerin aile geliri algıları değişkenine göre İslâm anlayışları alt boyutları varyans analizi (ANOVA) sonuçlarına bakıldığında aile geliri değişkeninin İslâm anlayışı ölçeği alt boyutlarından tasavvufî, modernist ve siyasal İslâm anlayışı boyutlarının puan ortalamaları arasında anlamlı düzeyde farklılaştığı tespit edilmiştir. Farklılıkların hangi gelir düzeyi ortalamalarından kaynaklandığını belirlemek amacıyla posthoc LSD analizi yapılmıştır.

Post-hoc LSD analizi sonucunda tasavvufî İslâm anlayışı kategorisinde aile gelirini düşük olarak gören öğrencilerin $(X=3.98)$, gelirlerinin orta $(X=3.80)$ düzeyde olduğunu ifade eden öğrencilere göre daha yüksek düzeyde tasavvufî İslâm anlayışına sahip oldukları ortaya çıkmıştır. Aşlamacı da tasavvufî İslâm anlayışında düşük aile gelirine sahip olduklarını belirten öğrencilerin orta ve yüksek düzeyde gelire sahip olan öğrencilere göre daha yüksek düzeyde tasavvufî İslâm anlayışına sahip olduklarını tespit etmiştir. ${ }^{37}$ Modernist İslâm anlayışı boyutuna bakıldığında, post-hoc LSD analizi sonuçları, tasavvufî İslâm anlayışının aksine, aile gelirlerinin orta düzey olduğunu ifade eden öğrencilerle düşük düzeyde olduğunu ifade eden öğrenciler arasında anlamlı farklılaşmanın olduğunu ortaya koymuştur. Analiz sonucuna bakıldığında, orta düzey aile gelirine sahip öğrencilerin $(X=2,86)$, düşük düzey $(X=2,71)$ aile gelirine sahip olduklarını belirten öğrencilere göre daha yüksek düzeyde modernist İslâm anlayışına sahip oldukları görülmektedir. Araştırmamızda bu değişkende ulaşılan sonuçlar, Aşlamacı'nın araştırmasının aynı değişkende ulaştığı sonuçlarla karşılaştırıldığında bir paralellik söz konusudur. ${ }^{38}$ Siyasal İslâm anlayışı boyutunda da post-hoc LSD analizi sonuçları, modernist İslâm anlayışına benzer şekilde, aile gelirlerinin düşük düzey olduğunu ifade eden öğrencilerle orta düzeyde olduğunu ifade eden öğrenciler arasında anlamlı farklılaşmanın olduğunu ortaya koymuştur. Analiz sonucu, düşük düzey aile gelirine sahip öğrencilerin $(X=1,97)$, orta düzey $(X=2,79)$ aile gelirine sahip olduklarını belirten öğrencilere göre daha düşük düzeyde siyasal İslâm anlayışına sahip

\footnotetext{
37 Aşlamacı, "İlahiyat Fakültesi Öğrencilerinin İslâm Anlayışları Üzerine Bir İnceleme (İnönü Üniversitesi Örneği)", 478.

38 Aşlamacı, "İlahiyat Fakültesi Öğrencilerinin İslâm Anlayışları Üzerine Bir İnceleme (İnönü Üniversitesi Örneği)", 478.
} 
olduklarını ortaya koymaktadır. Aşlamacı'nın çalışmasında ${ }^{39}$ selefi ve siyasal İslâm alt boyutlarında, çalışmamızda ise sadece selefí İslâm alt boyutunda bir farklılık ortaya çıkmamıştır.

Tablo 5: Mezun Olunan Lise Değişkenine Göre İslâm Anlayışı Boyutlarına Ait t Testi Analizi

\begin{tabular}{|c|c|c|c|c|c|c|}
\hline Boyutlar & Cinsiyet & $\mathbf{N}$ & $\mathrm{X}$ & Ss. & $\mathbf{t}$ & $\mathbf{P}$ \\
\hline \multirow{2}{*}{ Tasavvufî İslâm Anlayışı } & İHL/AİHL & 261 & 3.93 & .93 & \multirow{2}{*}{.621} & \multirow{2}{*}{.535} \\
\hline & Diğer Liseler & 180 & 3.87 & .86 & & \\
\hline \multirow{2}{*}{$\begin{array}{l}\text { Modernist İslâm Anla- } \\
\text { yı̧̧ı }\end{array}$} & İHL/AİHL & 261 & 2.73 & .79 & \multirow{2}{*}{-1.32} & \multirow{2}{*}{.189} \\
\hline & Diğer Liseler & 180 & 2.83 & .75 & & \\
\hline \multirow{2}{*}{ Siyasal İslâm Anlayışı } & İHL/AİHL & 261 & 1.89 & .80 & \multirow{2}{*}{-.531} & \multirow{2}{*}{.596} \\
\hline & Diğer Liseler & 180 & 1.93 & .78 & & \\
\hline \multirow{2}{*}{ Selefi İslâm Anlayışı } & İHL/AİHL & 261 & 3.31 & .85 & \multirow{2}{*}{3.90} & \multirow{2}{*}{.001} \\
\hline & Diğer Liseler & 180 & 2.98 & .86 & & \\
\hline
\end{tabular}

Tablo 5'te görüldüğü üzere, İslâm anlayış ölçeği alt boyutlarından Tasavvufî, modernist ve siyasal İslâm anlayışları alt boyutlarının puan ortalamaları arasında mezun olunan lise değişkenine göre istatistiksel olarak anlamlı bir farklılığın oluşmadığı, Selefî İslâm anlayışında ise oluştuğu görülmektedir. Selefî İslâm anlayışı alt boyutunda İHL/AİHL mezunlarının aritmetik ortalaması $(\mathrm{X}=3.31)$ ile diğer liselerden mezun olan öğrencilerin aritmetik ortalaması $(X=2.98)$ arasındaki farkın anlamlılığını göstermek amaciyla $t$ değerinin $(t=3.90, \mathrm{p}<.01) .01$ düzeyinde anlamlı bir farklılık olduğu tespit edilmiştir. Analizin sonucu, İmam-Hatip Liselerinden mezun olan öğrencilerin diğer liselerden mezun olan öğrencilerden daha yüksek düzeyde selefi İslâm anlayışına sahip olduklarını ortaya koymaktadır. Tasavvufî, modernist ve siyasal İslâm anlayışı alt boyutlarında ise mezun olunan lise türüyle öğrencilerin benimsediği din anlayışları arasında anlamlı bir farklılığın olmadığı görülmektedir.

39 Aşlamacı, "İlahiyat Fakültesi Öğrencilerinin İslâm Anlayışları Üzerine Bir İnceleme (İnönü Üniversitesi Örneği)”, 477. 
Mezun olunan lise türünün İlahiyat fakültesi öğrencilerinin din anlayışları üzerinde bir etkiye sahip olup olmadığına yönelik çalışmalar da farklı sonuçlar ortaya çıkmıştır. Örneğin, Akyüz'ün araştırmasında siyasal İslâm anlayışında lise türü değişkenine göre İmam Hatip Liselerinden mezun olan öğrencilerin katılım düzeyi genel liselerden mezun olan öğrencilerinden çok daha yüksek bulunmuştur. Buna karş1ık aynı çalı̧̧mada modernist din anlayışında ise anlamlı bir farklılık ortaya çıkmamıştır. ${ }^{40}$ Aşlamacı'nın araştırmasında selefî din anlayışında mezun olunan lise türü değişkenine göre anlamlı bir farklılık bulunmamışken modernist din anlayışında anlamlı bir farklılık ortaya çıkmıştır. ${ }^{41}$ Akkır'ın çalışmasında ise mezun olunan lise türü ile hiçbir İslâm anlayışı alt boyutu arasında anlamlı bir farklılık tespit edilmemiştir. ${ }^{42}$

Tablo 6: Sınıf Değişkenine Göre İslâm Anlayışı Boyutlarına Ait ANOVA Testi Analizi

\begin{tabular}{|c|c|c|c|c|c|c|c|}
\hline Boyutlar & Sinif & $\mathbf{N}$ & $\mathrm{X}$ & Ss & $\mathbf{F}$ & $\mathbf{p}$ & LSD \\
\hline \multirow{4}{*}{$\begin{array}{c}\text { Tasavvufî̀ } \\
\text { İslâm Anlayış1 }\end{array}$} & 1. Sinif & 103 & 3.90 & .84 & \multirow{4}{*}{.405} & \multirow{4}{*}{.687} & \multirow{4}{*}{--} \\
\hline & 2. Sinif & 110 & 3.97 & .90 & & & \\
\hline & 3. Sinif & 90 & 3.94 & .82 & & & \\
\hline & 4. Sinif & 138 & 3.84 & 1.01 & & & \\
\hline \multirow{4}{*}{$\begin{array}{l}\text { Modernist } \\
\text { İslâm Anlayış1 }\end{array}$} & 1. Sinif & 103 & 2.86 & .69 & \multirow{4}{*}{1.121} & \multirow{4}{*}{.340} & \multirow{4}{*}{--} \\
\hline & 2. Sinif & 110 & 2.74 & .80 & & & \\
\hline & 3. Sinif & 90 & 2.83 & .75 & & & \\
\hline & 4. Sinif & 138 & 2.70 & .83 & & & \\
\hline \multirow{4}{*}{$\begin{array}{c}\text { Siyasal } \\
\text { İslâm Anlayışı }\end{array}$} & 1. Sinif & 103 & 1.95 & .69 & \multirow{4}{*}{.364} & \multirow{4}{*}{.779} & \multirow[t]{4}{*}{--} \\
\hline & 2. Sinif & 110 & 1.86 & .82 & & & \\
\hline & 3. Sinif & 90 & 1.87 & .74 & & & \\
\hline & 4. Sinif & 138 & 1.93 & .87 & & & \\
\hline
\end{tabular}

\footnotetext{
40 Akyüz, İlahiyat Fakültesi Öğrencilerinin Din Anlayışı, 92-100.

41 Aşlamacı, "İlahiyat Fakültesi Öğrencilerinin İslâm Anlayışları Üzerine Bir İnceleme (İnönü Üniversitesi Örneği)”, 477.

42 Akkır, "İlahiyat Fakültesi Öğrencilerinin Din Anlayışı”, 466.
} 


\begin{tabular}{|c|c|c|c|c|c|c|c|}
\hline \multirow{4}{*}{$\begin{array}{c}\text { Selefî̀ } \\
\text { İslâm Anlayış1 }\end{array}$} & 1. Sinıf & 103 & 2.72 & .70 & \multirow{4}{*}{17.137} & \multirow{4}{*}{.001} & \multirow{4}{*}{$\begin{array}{l}1-2 \\
1-3 \\
1-4 \\
2-4\end{array}$} \\
\hline & 2. Sinif & 110 & 3.12 & .89 & & & \\
\hline & 3. Sinif & 90 & 3.27 & .88 & & & \\
\hline & 4. Sinıf & 138 & 3.48 & .82 & & & \\
\hline
\end{tabular}

Tablo 6'da sınıf değişkenine göre İslâm anlayışları alt boyutları puan ortalamaları arasında anlamlı bir farklılaşmanın olup olmadığını görebilmek için yapılan tek yönlü varyans analizleri sonuçlar yer almaktadır. Yapılan analiz sonucunda sınıf değişkenine göre sadece selefî İslâm anlayışı alt boyutu puan ortalamaları arsında anlamlı düzeyde bir farklılık ortaya çıkmıştır. Farklılıkların hangi sınıflar arasında olduğunu belirlemek üzere post-hoc LSD analizi yapılmıştır. Analiz sonucunda, 4. Sınıflar ile 1. ve 2. sinıflar arasında ve 3. sinıflar ile de 1. siniflar arasında anlamlı farkl1lıkların olduğu ortaya çıktı. Buna göre, en yüksek düzeyde 4. sınıfların (X=3.48) selefî İslâm anlayışına sahip oldukları görülürken en düşük düzeyde ise 1. sınıfların $(X=2.72)$ söz konusu anlayışı benimsedikleri tespit edilmiştir.

Tablo 7: İlahiyat Fakültesinde Olması Gereken Eğitim Türü Değişkenine Göre İslâm Anlayışı Boyutlarına Ait ANOVA Testi Analizi

\begin{tabular}{|c|c|c|c|c|c|c|c|}
\hline Boyutlar & & $\mathbf{N}$ & $\mathbf{X}$ & Ss & $\mathbf{F}$ & $\mathbf{p}$ & LSD \\
\hline \multirow{3}{*}{$\begin{array}{c}\text { Tasavvufî } \\
\text { İslâm Anlayış1 }\end{array}$} & Karma olmalıdır & 229 & 4.14 & .77 & \multirow{3}{*}{17.524} & \multirow{3}{*}{.001} & \multirow{3}{*}{$\begin{array}{l}1-2 \\
1-3\end{array}$} \\
\hline & Ayrı olmalıdır & 176 & 3.63 & 1.02 & & & \\
\hline & Fikrim yok & 36 & 3.81 & .60 & & & \\
\hline \multirow{3}{*}{$\begin{array}{l}\text { Modernist } \\
\text { İslâm Anlayış1 }\end{array}$} & Karma olmalıdır & 229 & 2.47 & .71 & \multirow{3}{*}{47.680} & \multirow{3}{*}{.001} & \multirow{3}{*}{$\begin{array}{l}1-2 \\
1-3\end{array}$} \\
\hline & Ayrı olmalıdır & 176 & 3.16 & .73 & & & \\
\hline & Fikrim yok & 36 & 2.78 & .55 & & & \\
\hline \multirow{3}{*}{$\begin{array}{c}\text { Siyasal } \\
\text { İslâm Anlayış1 }\end{array}$} & Karma olmalıdır & 229 & 2.14 & .85 & \multirow{3}{*}{30.854} & \multirow{3}{*}{.001} & \multirow{3}{*}{$1-2$} \\
\hline & Ayrı olmalıdır & 176 & 1.57 & .62 & & & \\
\hline & Fikrim yok & 36 & 2.06 & .54 & & & \\
\hline
\end{tabular}




\begin{tabular}{|c|l|l|l|l|l|l|l|}
\hline \multirow{4}{*}{$\begin{array}{c}\text { Selefi } \\
\text { İslâm Anlayışı }\end{array}$} & Karma olmalıdır & 229 & 3.20 & .88 & & & \\
\cline { 2 - 5 } & Ayrı olmalıdır & 176 & 3.17 & .86 & \multirow{3}{*}{.949} & \multirow{2}{*}{.388} & \multirow{2}{*}{-} \\
\cline { 2 - 5 } & Fikrim yok & 36 & 2.99 & .85 & & & \\
\hline
\end{tabular}

Tablo 7, İlahiyat fakültelerinde eğitimin nasıl olması gerektiği konusunda öğrencilerin tutumlarını ölçmektedir. Yapılan varyans analizi sonucu, İlahiyat Fakültesinde olması gereken eğitim türü değişkenine göre ölçeğin tasavvufî, modernist ve siyasal İslâm anlayışları boyutlarının puan ortalamaları arasında anlamlı farklılıkların olduğu saptanmıştır. Bu farklılıkların İlahiyat Fakültesindeki eğitimin nasıl olması gerektiğine ilişkin tutumlardan hangileri arasında olduğunu belirlemek amaciyla post-hoc LSD analizi yapılmıştır. Buna göre, Tasavvufî İslâm anlayışı alt boyutunda karma eğitimin olması gerektiğini düşünen öğrencilerin $(X=4.14), k 1 z$ ve erkek öğrencilerin farklı sınıflarda eğitim almaları gerektiğini düşünen $(X=3.63)$ ve fikir belirtmeyen (X=3.81) öğrencilere oranla daha yüksek düzeyde bir katılıma sahip oldukları ortaya çıkmıştır. Bu alt boyutta karma eğitim olması gerektiğini belirten öğrencilerle diğer iki grup arasında anlamlı bir fark ortaya çıkmışır.

Analiz sonucunda siyasal İslâm anlayışı alt boyutunda İlahiyat Fakültesinde kız ve erkeklerin ayrı sınıflarda eğitim görmeleri gerektiğini ifade eden öğrencilerin katılım düzeyleri $(X=3.16)$, karma eğitim olması gerektiğini düşünen $(X=2.47)$ ve fikir belirtmeyen $(X=2.78)$ öğrencilere göre daha yüksek bulunmuştur. Bu alt boyutta da karma eğitimi savunanlar ile diğer iki grup arasında anlamlı bir farkın olduğu saptanmıştır.

Siyasal İslâm anlayışı alt boyutunda ise karma eğitim olması gerektiğini söyleyenler $(X=2.14)$ ile kız ve erkeklerin farklı sınılarda eğitim görmeleri gerektiğini belirten öğrenciler $(\mathrm{X}=1.57)$ arasında anlamlı bir farklılık olmuştur. İlahiyat fakültesinde karma eğitim olması gerektiğini belirten öğrencilerin siyasal İslâm alt boyutunda daha yüksek düzeyde bir katılım gösterdikleri tespit edilmiştir. 
Tablo 8: Öğrencinin İlahiyat Fakültesindeki Ders Gruplarından Hangisine Yakınlık Duyduğu Değişkenine Göre İslâm Anlayışı Boyutlarına Ait ANOVA Testi Analizi

\begin{tabular}{|c|c|c|c|c|c|c|c|}
\hline Boyutlar & & $\mathbf{N}$ & $\mathrm{X}$ & Ss & $\mathbf{F}$ & $\mathbf{p}$ & LSD \\
\hline \multirow{3}{*}{$\begin{array}{l}\text { Tasavvufî } \\
\text { İslâm } \\
\text { Anlayışı }\end{array}$} & Temel İslâm & 239 & 3.69 & .97 & \multirow{3}{*}{18.613} & \multirow{3}{*}{.001} & \multirow{3}{*}{$\begin{array}{l}1-2 \\
2-3\end{array}$} \\
\hline & Felsefe-Din & 167 & 4.23 & .70 & & & \\
\hline & $\begin{array}{l}\text { İslâm Tarihi ve Sanat- } \\
\text { ları }\end{array}$ & 35 & 3.85 & .90 & & & \\
\hline \multirow{3}{*}{$\begin{array}{l}\text { Modernist } \\
\text { İslâm } \\
\text { Anlayışı }\end{array}$} & Temel İslâm & 239 & 3.09 & .70 & \multirow{3}{*}{52.756} & \multirow{3}{*}{.001} & \multirow{3}{*}{$\begin{array}{l}1-2 \\
1-3\end{array}$} \\
\hline & Felsefe-Din & 167 & 2.38 & .69 & & & \\
\hline & $\begin{array}{l}\text { İslâm Tarihi ve Sanat- } \\
\text { ları }\end{array}$ & 35 & 2.54 & .72 & & & \\
\hline \multirow{3}{*}{$\begin{array}{l}\text { Siyasal } \\
\text { İslâm } \\
\text { Anlayış1 }\end{array}$} & Temel İslâm & 239 & 1.66 & .65 & \multirow{3}{*}{29.324} & \multirow{3}{*}{.001} & \multirow{3}{*}{$\begin{array}{l}1-2 \\
1-3\end{array}$} \\
\hline & Felsefe-Din & 167 & 2.20 & .83 & & & \\
\hline & $\begin{array}{l}\text { İslâm Tarihi ve Sanat- } \\
\text { lar1 }\end{array}$ & 35 & 2.22 & .88 & & & \\
\hline \multirow{3}{*}{$\begin{array}{l}\text { Selefi } \\
\text { İslâm } \\
\text { Anlayış1 }\end{array}$} & Temel İslâm & 239 & 3.10 & .91 & \multirow{3}{*}{3.036} & \multirow{3}{*}{.049} & \multirow{3}{*}{$1-2$} \\
\hline & Felsefe-Din & 167 & 3.30 & .84 & & & \\
\hline & $\begin{array}{l}\text { İslâm Tarihi ve Sanat- } \\
\text { ları }\end{array}$ & 35 & 3.04 & .69 & & & \\
\hline
\end{tabular}

Tablo 8'deki veriler öğrencilerin İlahiyat Fakültesinde ilgi duyduğu ders grupları değişkenine göre dört İslâmî anlayış alt boyutların tamamında puan ortalamaları düzeyinde bir farklılaşmanın olduğu tespit edilmiştir. Farklılıkların değişkendeki hangi gruplar arasında olduğunu belirleyebilmek için post-hoc LSD analizi yapılmıştır. Analiz sonucunda tasavvufî İslâm anlayışı alt boyutunda Felsefe ve Din Bilimleri ders grubuna ilgi duyanlar ile hem Temel İslâm Bilimleri ders grubuna ilgi duyan hem de İslâm Tarihi ve Sanatları ders grubuna ilgi duyan ögrenciler arasında anlamlı bir farklılık saptanmıştır. Öte yandan Felsefe ve Din Bilimleri ders grubuna yakınlık duyan öğrencilerin tasavvufî İslâm anlayışına en yüksek düzeyde (X=4.23) katılım gösterdikleri belirlenmiştir. 
Modernist İslâm anlayışına ilişkin yapılan post-hoc LSD analizi sonucunda kendilerini Temel İslâm Bilimleri ders grubuna yakın gören öğrencilerin $(X=3.09)$ en yüksek katılım düzeyine sahip oldukları sonucuna varılmıştır. Bu alt boyutta Temel İslâm Bilimlerine ilgi duyan öğrenci grubu ile diğer iki grup arasında anlamlı bir farkın olduğu tespit edilmiştir.

Post-hoc LSD testi sonucunda siyasal İslâm anlayışı alt boyutunda en düşük katılım gösteren öğrenci grubu kendilerini Temel İslâm Bilimleri ders grubuna en yakın görenlerdir $(X=1.66)$. Bu alt boyutta da Temel İslâm Bilimleri ders grubuna ilgi duyanlar ile diğer iki grup arasında anlamlı bir fark ortaya çıkmıştır. Siyasal İslâm alt boyutuna en yüksek düzeyde katılım gösteren grup ise İslâm Tarihi ve Sanatları ders grubuna ilgi duyduklarını belirten öğrenciler olmuştur. Ancak bu grubun katılım düzeyi (X=2.22) ile kendilerini Felsefe ve Din grubu derslerine yakın gören öğrencilerin kat1lım düzeyleri $(X=2.20)$ arasında anlamlı bir farklilık bulunmamaktadır.

Selefî İslâm anlayışı açısından analizin sonuçlarına bakıldığında, Temel İslâm Bilimleri ders grubuna yakınlık duyan öğrenciler ile Felsefe ve Din Bilimleri ders grubuna yakınlık duyan öğrenciler arasına anlamlı bir farklılığın bulunduğu görülmektedir. Felsefe ve Din Bilimleri ders grubuna ilgi duyanların $(X=3,30)$ diğer gruplara nazaran daha yüksek düzeyde selefî İslâm anlayışına sahip oldukları tespit edilmiştir.

\section{Sonuç}

Bu çalı̧̧ma, 2020-2021 eğitim-öğretim döneminde Van Yüzüncü Yı1 Üniversitesi İlahiyat Fakültesinde okuyan öğrencilerin sahip oldukları dinî anlayışı çeşitli değişkenler açısından ele alarak tespit etmeye odaklanmaktadır. Araştırmada varılan sonuçları ve bu sonuçlara ilişkin değerlendirmeleri genel olarak şu şekilde özetlemek mümkündür:

Öğrencilerin sahip oldukları İslâm anlayışları en yüksekten başlamak koşuluyla ortalama puanları sırasıyla tasavvufi İslâm anlayışı, selefî İslâm anlayışı, modernist İslâm anlayışı ve siyasal İslâm anlayışı olarak gerçekleşmiştir. Bu verilere göre, öğrencilerin tasavvufî İslâm anlayışlarına katılım düzeyleri yüksek, modernist ve selefî İslâm anlayışlarına katılım düzeyleri orta ve siyasal İslâm anlayışına katılım düzeyleri ise düşük derecededir. Tasavvufî eğilim son dönemlerde dünya ölçeğinde bir yükseliş trendine sa- 
hiptir. Bu trendi, gerek TV, internet ve uydu teknolojisi gibi kitle iletişim araçlarının aracılık ettiği mecralarda yer alan ve son dönemde giderek artan yayınlardan, gerekse dergi, kitap, makale gibi yayıncılık dünyasının ürünlerinin artmasından takip etmek mümkündür. Tasavvufî eğilimin yükselişinin kuşkusuz farklı nedenleri bulunmaktadır. Ancak modern dünyanın insanın manevi boyutunu ihmal eden niteliği bu yükselişin en temel nedenlerinden biri olarak görülebilir. Modern dünyanın hazzı merkeze alan ve bitip tükenmek bilmeyen maddeci tüketim kültürünün yol açtığı manevi boşluk tüm dünyada mistik anlayışlara duyulan ilgiyi arttırmaktadır. Modernist ve selefî İslâm anlayışlarıyla ilgili son dönemlerde yaşanan tartışmaların öğrencilerin eğilimlerinde bir etki unsuru olduğu söylenebilir. Bilhassa modernist İslâm anlayışının fazla rağbet görmemesinin onun dinin içeriğini boşaltma ya da onu başkalaştırma suçlamalarına maruz kalmasıyla bağlant1lı olduğunu söylemek mümkündür. Öte yandan, siyasal İslâm anlayışının öğrenciler arasında rağbet görmemesi de dikkatleri çekmektedir. Burada da değişik unsurların rol aldığı bir sürecin söz konusu olduğunu teslim etmekle birlikte, şeriatla yönetildiği ileri sürülen ülkelerin içinde bulundukları siyasi, ekonomik ve hukuki problemlerin bireylerde yol açmış olduğu algı ile siyasal İslâmcı hareketlerin başarılı olamamaları bu anlayışa ilişkin yönelimin zayıf kalmasına neden olan önemli faktörlerden biri olabileceği mülahaza edilmektedir.

Cinsiyet değişkenine göre tasavvufî, modernist ve selefî İslâm anlayışları alt boyutlarında anlamlı farklılaşma olduğu, buna karşılık siyasal İslâm aşlayışında ise olmadığı tespit edilmiştir. Buna göre kız öğrencilerin erkek öğrencilere göre daha yüksek düzeyde tasavvufî İslâm anlayışına sahip oldukları; erkek öğrencilerin kız öğrencilere göre daha yüksek düzeyde modernist İslâm anlayışına sahip oldukları ve erkek öğrencilerin kız öğrencilere göre daha yüksek düzeyde selefî İslâm anlayışına sahip oldukları saptanmıştır. Tasavvufî İslâm anlayı̧̧ının kız öğrenciler, modernist İslâm anlayışının ise daha fazla erkek öğrenciler arasında karşılık bulması kadın ve erkek dindarlığıyla bağlantılı bir şekilde açılamak mümkündür. Genel olarak, ataerkil aile yapılarında sıkı ve kontrollü koşullar altında kızların aile içinde daha fazla kısıtlanmaları, erkeklere nazaran daha az bağımsız davranmalarına izin verilmesi, sosyal olarak daha zor koşullarda yaşamaları onların bir başa çıkma yöntemi olarak manevi 
alanlara yönelmelerinde etkili bir faktör olarak rol oynamaktadır. ${ }^{43}$ Ayrıca kişilik özellikleri açısından psikolojik olarak erkeklere göre daha fazla mistisizme ve dine yatkın olmaları da kadınların tasavvufa yönelmelerinde bir faktör olarak değerlendirilebilir. Modernist din anlayışının erkeklerde daha yaygın çıkmasının nedenleri arasında da yaşantılar önemli bir yer tutmaktadır. Aile içerisinde daha serbest bir biçimde yetişmeyi, kendilerine güvenmeyi öğrenmeleri ve dışarıda geniş bir özgürlük alanını deneyimlemeleri onları modernist eğilimlere daha yatkın hale getirmektedir.

Öğrencilerin algıladıkları aile geliri değişkenine göre tasavvufî, modernist ve siyasal İslâm anlayışları boyutlarında anlamlı farklılaşma olduğu saptanmı̧̧ır. Buna göre aile gelirlerinin düşük düzeyde olduğunu belirten öğrencilerin orta düzeyde olduğunu ifade eden öğrencilere göre daha yüksek düzeyde tasavvufî İslâm anlayışına sahip oldukları; bununla uyumlu olarak düşük düzey aile gelirine sahip öğrenciler orta düzey aile gelirine sahip öğrencilere göre daha düşük düzeyde modernist İslâm anlayışına sahip oldukları ve orta düzey gelire sahip olanların düşük düzey gelire sahip olan öğrencilere göre daha yüksek düzeyde siyasal İslâm anlayışına sahip oldukları tespit edilmiştir.

Mezun olunan lise türü değişkenine göre sadece selefî İslâm anlayışı boyutunda anlamlı farklılaşma olduğu saptanmıştır. Buna göre İmam Hatip liselerinden mezun olan öğrencilerin diğer lise türlerinden mezun olan öğrencilere göre daha yüksek düzeyde selefî İslâm anlayışına sahip oldukları tespit edilmiştir. Sınıf değişkeni açısından bakıldığında da sadece selefî İslâm anlayışı boyutunda anlamlı bir farklılaşmanın olduğu sonucu çıkmıştır. Test sonucuna göre, 4. sınıflar selefî İslâm anlayışına en yüksek düzeyde katılım gösterirken onları sirasıyla 3. sinıflar, 2. sinıflar ve 1. sinıflar takip etmektedir. Diğer bir anlatımla selefî İslâm anlayışı, öğrenciler eğitim-öğretim sürecinde ilerledikçe etkisini artırmı̧̧ır. Selefilik günümüzde yükselişte olan bir dinî hareket olarak görülmektedir. Bu yükselişin dinî, siyasi, ekonomik, sosyokültürel, psikolojik ve coğrafi olanların yanı sıra onun ideolojik yapısı ve zihin kodları da yer almaktadır. Cihat, hicret, İslâm devleti gibi kavramlar etrafında 
üretilen ideolojinin selefilliği kimi insanlar için cazip kıldığı selefilik ile ilgili çalışmalarda yer almaktadır. Son dönemlerde özellikle Batı'da İslâmofobik eğilimlerde yaşanan artış, İslâm ve yabancı karşıtlığı, Suriye, Afganistan, Irak gibi İslâm coğrafyasında yaşanan savaş ve çatışmalar da Batı'nın oynadığı role ilişkin algılar selefilik gibi radikal unsurlara olan teveccühü arttırmaktadır ${ }^{44}$. Bununla birlikte, araştırmamızda öğrenciler arasında selefî din anlayışına dair ortaya çıkan yönelimi sadece bu sebeplere bağlamak için elimizde yeteri kadar veri bulunmamaktadır. Daha sağlıklı bilgilere ulaşmak için daha ileri ve nitel araştırmalara ihtiyaç duyulmaktadır.

İlahiyat fakültelerinde olması gereken eğitim türü değişkenine göre tasavvufî, modernist ve siyasal İslâm anlayışları boyutlarında anlamlı farklilaşma olduğu saptanmıştır. Buna göre, İlahiyat fakültelerinde öğrencilerin karma eğitim yöntemiyle eğitim almaları gerektiğini belirten öğrencilerin kız ve erkek öğrencilerin ayrı sınıflarda eğitim görmeleri gerektiğini ifade eden ve "fikrim yok" diyen öğrencilere göre daha yüksek düzeyde tasavvufî İslâm anlayışına sahip oldukları; ayrı sınıflarda eğitimin olması gerektiğini ifade eden öğrencilerin karma olması gerektiğini ifade eden ve "fikrim yok" diyen öğrencilere göre daha yüksek düzeyde modernist İslâm anlayışına sahip oldukları ve İlahiyat fakültelerinde karma eğitim olması gerektiğini düşünen öğrencilerin kız ve erkek öğrencilerin ayrı sınıflarda eğitim görmeleri gerektiğini ifade eden öğrencilere göre daha yüksek düzeyde siyasal İslâm anlayışına sahip oldukları tespit edilmiştir. İlahiyat fakültelerindeki ders gruplarına duyulan yakınlık değişkenine göre ise dört boyutta da anlamlı farkl11kların olduğu tespit edilmiştir. Testin sonucuna göre, Felsefe ve Din bilimleri ders grubuna ilgi duyan öğrenciler Temel İslâm Bilimleri ile İslâm Tarihi ve Sanatları ders gruplarına ilgi duyan öğrencilere göre daha yüksek düzeyde Tasavvufî İslâm anlayışına sahiptir. Modernist İslâm anlayı̧̧ını en fazla benimseyen öğrenci grubunun Temel İslâm Bilimleri ders grubuna ilgi duyduklarını belirten öğrenciler oldukları; siyasal İslâm anlayışının en fazla İslâm Tarihi ve Sanatları ile Felsefe ve Din Bilimleri ders grubuna

44 Bilal Sambur, "Bir fundamentalist ideoloji: Selefilikten Selefizme", ŞARKUL AVSAT (Erişim 29 Ekim 2021); Özcan Hidır, “Radikal-entegrist' selefillik neden Batı'da yükseliyor?”, Anadolu Ajansı (Erişim 29 Ekim 2021). 
ilgi duyan öğrencilerin katılım düzeylerinin yüksek, Temel İslâm Bilimleri derslerine ilgi duyan öğrencilerin ise düşük düzeyde olduğu; selefî İslâm anlayışının ise en fazla Felsefe ve Din Bilimleri ders grubuna ilgi duyan öğrenciler tarafından sahiplendiği sonucuna ulaşılmıştır.

Araştırmada en fazla dikkat çeken unsur bu son iki değişkende kendini göstermiştir. Çünkü kişisel bilgi formu'unda yer alan demografik sorulara verdikleri yanıtlarla daha fazla modernist eğilimde olmaları beklenen öğrencilerin diğer din anlayışlarına daha fazla yönelim gösterdikleri tespit edilmiştir. Örneğin kişisel bilgi formunda katılımcılara İlahiyat Fakültelerinde öğrencilerin karma sınıflarda mı yoksa ayrı sınıflarda mı eğitim görmeleri gerektiğine ilişkin soruya öğrencilerin büyük bir bölümü tercihlerinin İlahiyat fakültelerinde karma eğitim verilmesi yönünde olmuştur. Ancak bu cevabı verenlerin ayrı sınıllarda eğitim verilmesi gerektiğini ifade edenlerden daha fazla tasavvufí İslâm anlayışına sahip oldukları görülmüş, ayrı sinıflarda eğitim verilmesi gerektiğini belirtenlerin ise modernist İslâm anlayışına daha fazla rağbet gösterdikleri saptanmıştır. Benzer şekilde, öğrencilere İlahiyat fakültelerinde okutulan ders gruplarından hangilerine ilgi duyduklarına yönelik soruya Felsefe ve Din Bilimleri ders grubuna ilgi duyduklarını belirten öğrencilerin en fazla sahiplendikleri İslâm anlayışı yine tasavvufî İslâm anlayışı olurken, Temel İslâm Bilimleri ders grubuna yakın olduğunu belirten öğrenciler ise nispeten daha uzak olmalarının beklendiği modernist İslâm anlayışına rağbet gösterdikleri sonucu çıkmıştır. Ayrıca, akla vurguyu geri plana iten selefî İslâm anlayışının da Felsefe ve Din Bilimleri ders grubuna ilgi duyduklarını ifade eden öğrenciler arasında daha fazla sahiplendiği bir başka ilgi çekici sonuç olarak karşımıza çıkmaktadır.

Sonuç olarak, ölçekte belirlenen dört İslâm anlayışına ilişkin değerlendirmelerin konuyla ilgili nihai değerlendirmeler olmadığını, onların sadece eldeki sınırlı veriler 1şığında öğrencilerin dinî anlayışlarına ilişkin sınırlı ölçüde bir değerlendirme olanağ1 sunduğunu göz önünde bulundurmak gerekmektedir. Ayrıca, İlahiyat fakültesi öğrencilerinin neden farklı dinî anlayışlara sahip olduklarına ilişkin bir sorgulama bu çalışmanın sınırlarının dışındadır. Dolayısıyla değişkenler ile eğilimler arasında bir korelasyon kurmak mümkün olmakla birlikte, bu korelasyon nitel boyutta test edilmemiş bir çıkarım düzeyinde kalmaktadır. Bu sebeple daha sağlıklı sonuçlara 
ulaşmak için nicel yöntemin yanında nitel yöntemi de esas alan daha ileri çalışmalara ihtiyaç duyulmaktadır.

\section{Kaynakça}

Ahmad, Khurshid. "Introduction". The Islamic Law and Constitution. 1-36. Lahore: Islamic Publication, 1980.

Akkır, Ramazan. "İlahiyat Fakültesi Öğrencilerinin Din Anlayışları: Tekirdağ Namık Kemal Üniversitesi İlahiyat Fakültesi Örneği”. Sïrt Üniversitesi İlahiyat Fakültesi Dergisi 7/2 (30 Aralık 2020), 443-472. https://dergipark.org. $\mathrm{tr} / \mathrm{tr} / \mathrm{pub} /$ siirtilahiyat/825945

Aktaş, Ahmet. “İlahiyat Eğitimi Gören Kız Öğrencilerin İslâm Anlayışları (Siirt Üniversitesi Örneği)”. Her Dem Kadın. Ed. Gülşen İstek. 321-348. İstanbul: Beyan Yayınları, 2021.

Akyüz, Niyazi. İlabiyat Fakültesi Öğrencilerinin Din Anlayışı. Ankara: Gündüz Eğitim ve Yayıncılık, 2007.

Akyüz, Niyazi. "İlahiyat Fakültesi Öğrencilerinin Din Anlayışı Ölçeği Üzerine Bir Pilot Araştırma”. Ankara Üniversitesi İlahiyat Fakültesi Dergisi 43/1 (01 Nisan 2002), 123-134. https://doi.org/10.1501/Ilhfak_0000000082

Amman, Mehmet Tayfun. "Anlamak ve Arınmak: Sosyoloji ile Tasavvuf Arasında Köprülerin Kurulması”. Akademik Platform İslami Araştırmalar Dergisi 1/1 (01 Şubat 2017), 18-22. https://dergipark.org.tr/en/pub/apjir/377264 Aşlamacı, İbrahim. "İlahiyat Fakültesi Öğrencilerinin İslâm Anlayışları Üzerine Bir İnceleme (İnönü Üniversitesi Örneği)”. İslam ve Yorum II. ed. Fikret Karaman. 457-483. Malatya: İnönü Üniversitesi Yayınevi, 2018.

Aydın, Mehmet S. "Fazlur Rahman ve İslâm Modernizmi”. İslâmi Araştırmalar Dergisi 4/4 (1990), 273-284.

Aydın, Mehmet S. “Rasyonel Düşünce ve İslâm Modernizmi”. I. İslam Düsüncesi Sempozyumu. ed. Mehmet Bekaroğlu. 147-154. İstanbul: Beyan Yayınları, 1995.

Cutting, Marsha - Walsh, Michelle. "Religiosity Scales: What Are We Measuring in Whom?" Archive for the Psychology of Religion 30/1 (01 Ocak 2008), 137154. https://doi.org/10.1163/157361208X317006

Fichter, Joseph H. "Sociological Measurement of Religiosity”. Review of Religious Research 10/3 (1969), 169-177. https://doi.org/10.2307/3510744

Haddad, Yvonne Y. vd. The Contemporary Islamic Revival: A Critical Survey and Bibliograpy. Westport: Greenwood, 1991. 
Hıdır, Özcan. “Radikal-entegrist' selefîlik neden Batı'da yükseliyor?” Anadolu Ajansı. Erişim 29 Ekim 2021. https://www.aa.com.tr/tr/analiz-haber/ radikal-entegrist-selefîlik-neden-bati-da-yukseliyor/740850

İnan, Ali. “Sosyal Sermaye Bağlamında Bölüm Memnuniyeti ve Sosyal Ağ Olarak Okul Ortamına Bakış İlişkisi: İlahiyat Fakülteleri Örneği”. Türkiye Din Ĕ̈itimi Araştırmaları Dergisi 8 (29 Aralık 2019), 11-26. https://dergipark. org.tr/tr/pub/tudear/667009

İşcan, Mehmet Zeki. “Tarih Boyunca Selefî Söylem”. İlabiyat Akademi 1-2 (19 Ekim 2015), 1-14. https://dergipark.org.tr/tr/pub/ilak/106559

Kalgi, Mehmet Emin vd. "Lisans Öğrencilerinin Değer Yönelimleri: Karşılaştırmalı Bir Analiz-Van Yüzüncü Y1l Üniversitesi Örneği”. BEÜ İlabiyat Fakültesi Dergisi 7/2 (15 Aralık 2020), 559-580. https://doi.org/10.33460/ beuifd.810238

Kayhan, Mutlu. "Bir Dindarlık Ölçeği (Sosyoloji'de Yöntem Üzerine Bir Tartışma)”. İslâmi Araştırmalar Dergisi 3/4 (1989), 194-199.

Khan, Muqtedar. "What Is Political Islam?” E-International Relations (2014). https://www.e-ir.info/2014/03/10/what-is-political-islam/

Kirman, Mehmet Ali. Din Sosyolojisi Terimleri Sözlüğü. İstanbul: Rağbet Yayınları, 2011.

Koca, Ferhat. "İslam Düşünce Tarihinde Selefilik: Tarihsel Serüveni ve Genel Karakteristiği”. Illabiyat Akademi 1-2 (19 Ekim 2015), 15-70. https://dergipark.org.tr/en/pub/ilak/106560

Krämer, Gudrun. "Political Islam". Encyclopedia of Islam and the Muslim World. ed. Richard C. Martin. 2/536-540. New York: Macmillan, 2004.

Kutlu, Sönmez. Çăgdaş İslamî Akımlar. Ankara: Fecr Yayınları, 2008.

Maududi, S. Abui A'la. Jihad in Islam. Lahore: Islamic Publication, 1939.

Öngören, Reşat. "Ehl-i Sünnet'te Tasavvufun Yeri”. Taribte ve Günümüzde Ehl-i Sünnet. ed. Mahmut Kaya vd. 157-172. İstanbul: Ensar Neşriyat, 2006.

Öngören, Reşat. "Şeyh”. TDV İslam Ansiklopedisi. 39/50-52. Ankara: TDV Yayınlar1, 2010.

Öngören, Reşat. “Tasavvuf”. TDV İslam Ansiklopedisi. 40/119-126. Ankara: TDV Yayınları, 2011. /tasavvuf

Prasad, Durga M. S. - Narayan, K.A. "Strengths and Weaknesses of Online Surveys". Journal of Humanities and Social Sciences 5/5 (2019), 31-38.

Qutb, Sayyid. "War, Peace and Islamic Jihad”. Modernsit and Fundamentalist Deba- 
tes in Islam. ed. Mansoor Moaddel - Kamran Talattof. 221-245. New York: Palgrave Macmillan, 2002.

Roy, Olivier. Siyasal İslamı̇n İfası. çev. Cüneyt Akalın. İstanbul: Metis Yayınları, 1993.

Sambur, Bilal. "Bir fundamentalist ideoloji: Selefilikten Selefizme". SSARKUL AVSAT. Erişim 29 Ekim 2021. https://turkish.aawsat.com/home/ article/2537856/profdr-bilal-sambur/bir-fundamentalist-ideolojiselefilikten-selefizme

Sönmez, Mustafa. "İslâm Modernizminin Doğuşu ve İki Önemli Temsilcisi (Afgânî ve Abduh'un Modernist Yönlerine Kısa Bir Bakış)”. Atatürk Üniversitesi İlahiyat Fakültesi Dergisi 18 (30 Aralık 2002), 147-172. https:// dergipark.org.tr/en/pub/atauniilah/36322

Taş, Kemaleddin. "Dindarlığın Kriterleri Üzerine Tipolojik Bir Araştırma”. Dindarlğın Sosyo-Psikolojisi. 175-206. Adana: Karahan Kitapevi, 2006.

Tavşanc1, Ezel. Tutumların Ölçülmesi ve SPSS ile Veri Analizi. Ankara: Nobel Yayincilik, 2002.

Uysal, Veysel. "İslamî Dindarlık Ölçeği Üzerine Bir Pilot Çalı̧̧ma”. İslâmi Araştvrmalar Dergisi 8/3-4 (1995), 263-271. http://www.islamiarastirmalar. com/magazine/en-islm-dindarlIk-olcegi-cizerine-bir-pilot-callsma-457. html? page $=$ archive

Voll, John O. "Salafiyya". Encyclopedia of Islam and the Muslim World. ed. Richard C. Martin. 2/608-610. New York: Macmillan, 2004.

Yakut, İdris - Taş, Kemaleddin. "İran'da Üniversite Öğrencilerinin Din Anlayış1 Üzerine Bir Ölçek Çalışması”. Journal of International Social Research 13/ (13/72) Theology (01 Ocak 2020), 1025-1032. https://doi.org/10.17719/ jisr.10915

Yapıc1, Asım. "Cinsiyete Göre Farklılaşan Dindarlıklar ve Kadınlarda Dinsel Yaşamın Farklı Görüntüleri”. Dini Araştrmalar 19/49 (24 Kasım 2016), 131161. https://doi.org/10.15745/da.268813

“YÖK Universiteler”. Erişim 22 Ekim 2021. https://www.yok.gov.tr/universiteler/ universitelerimiz

"Yükseköğretim Bilgi Yönetim Sistemi”. Erişim 30 Ekim 2021. https://istatistik. yok.gov.tr/ 
Anket

Aşağıdaki İfadelere Sizin İçin En Uygun Olan Cevabı İşaretleyiniz

\begin{tabular}{|c|c|c|c|c|}
\hline & 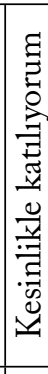 & ( & 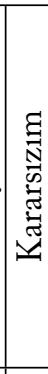 & 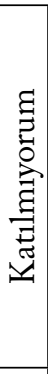 \\
\hline $\begin{array}{l}\text { İslâm'1 daha iyi yaşayabilmek için bir şeyhe/ mürşide } \\
\text { bağlanmak gerekir. }\end{array}$ & & & & \\
\hline $\begin{array}{l}\text { Bir evliyanın türbesinde yapılan duaların daha makbul } \\
\text { olduğunu düşünürüm. }\end{array}$ & & & & \\
\hline Tarikata bağlılık kişiyi daha dindar yapar. & & & & \\
\hline $\begin{array}{l}\text { İslâmî ahlaki ilkelerle bağdaştı̆̆ı sürece resim, müzik, heykel } \\
\text { gibi sanatlar dinimizce uygundur. }\end{array}$ & & & & \\
\hline $\begin{array}{l}\text { Cübbe, sarık, sakal gibi unsurlar dinden daha çok kültürle } \\
\text { ilişkilidir. }\end{array}$ & & & & \\
\hline $\begin{array}{l}\text { Kadının erkeklerin bulunduğu bir iş yerinde çalışı ailesinin } \\
\text { gelirine katkı sunması dinimizce caizdir. }\end{array}$ & & & & \\
\hline Akla uymayan bir hadis, uydurma bir hadistir. & & & & \\
\hline $\begin{array}{l}\text { İslâm dinine göre devlet yöneticilerinin kadın veya erkek } \\
\text { olması fark etmez. }\end{array}$ & & & & \\
\hline $\begin{array}{l}\text { İnsanlar arasında adaleti ve huzuru sağlayacak yegâne } \\
\text { kanunlar şeriat kanunlarıdır. }\end{array}$ & & & & \\
\hline $\begin{array}{l}\text { İslâmîbir devlet kurmakiçin mücadele etmek her Müslümanın } \\
\text { görevidir. }\end{array}$ & & & & \\
\hline $\begin{array}{l}\text { Batının sömürgeci düzenine karşı tüm Müslümanlar } \\
\text { birleşmelidir. }\end{array}$ & & & & \\
\hline $\begin{array}{l}\text { Din ile siyaset işlerinin birbirinden ayrılması İslâm'a uygun } \\
\text { değildir. }\end{array}$ & & & & \\
\hline $\begin{array}{l}\text { Kur'an ve sünnette bulunmayan her yeni şey bidat, her bidat } \\
\text { ise sapıklıktır. }\end{array}$ & & & & \\
\hline $\begin{array}{l}\text { Dinimiz fikhi mezheplere göre değil, hadisler esas alınarak } \\
\text { yaşanmalıdır. }\end{array}$ & & & & \\
\hline Namazı kasten terk eden kişi küfre girer. & & & & \\
\hline
\end{tabular}

